\title{
SKICA ZA POVIJEST NIJEMACA I AUSTRIJANACA U BOSNI I HERCEGOVINI, S POSEBNIM OSVRTOM NA NJIHOVU SUDBINU TIJEKOM DRUGOGA SVJETSKOG RATA I U PORAĆU
}

\author{
Vladimir GEIGER \\ Hrvatski institut za povijest \\ Opatička 10 \\ HR - 10000 Zagreb \\ E-pošta:geiger@isp.hr
}

\author{
UDK $323.1(497.6=112.2) " 1914 / 1958 "$ \\ $325(497.6=112.2) " 1914 / 1958 "$ \\ 94(497.6)"1914/1958" \\ Izvorni znanstveni rad \\ Primljeno: 28. veljače 2015 \\ Prihvaćeno: 9. ožujka 2015
}

\section{Sažetak}

Na temelju mnogobrojnih i najvrjednijih historiografskih, publicističkih i demografskih radova, te i objavljenih i arhivskih izvora prikazuje se povijest i promišlja sudbina Nijemaca i Austrijanaca Bosne i Hercegovine od vremena austrougarske okupacije i njihova naseljavanja potkraj 19. stoljeća, i razdoblja Kraljevine SHS/Jugoslavije, kada su, iako brojčano nevelika etnička skupina od dvadesetak tisuća, postali važan gospodarski i kulturni čimbenik, pa do razdoblja Drugoga svjetskog rata i neposrednoga poraća, kada su pretrpjeli znatne stvarne i demografske gubitke, i "nestali" iz bosanskohercegovačkoga područja.

Ključne riječi: Bosna i Hercegovina, Nijemci i Austrijanci. 
Nijemci u Bosni i Hercegovini najmlađa su njemačka kolonizacijska skupina u jugoistočnoj Europi. Od prisutnosti Germana iz vremena seobe naroda (Goti) i na Balkanu, i u Bosni i Hercegovini, ostale su samo "krhotine", ponajprije u djelima bizantskih pisaca, ali i različiti arheološki nalazi, ${ }^{1}$ a od prisutnosti stanovništva njemačkoga podrijetla uza srednjovjekovne rudokope (Sasi) u
Bosni i Hercegovini nalazimo ostatke prepoznatljive ponajprije $\mathrm{u}$ arheološkim nalazima i u toponimima. ${ }^{2}$

U vrijeme osmanske vladavine njemački su trapisti 1869. osnovali nedaleko od Banje Luke, u Delibašinu Selu, samostan Maria Stern/Marija Zvijezda. ${ }^{3}$ Značajnije skupine Nijemaca naselile su se u Bosnu i Hercegovinu u vrijeme austrougarske oku-

1 Usp. Žzцjко Demo, Ostrogothic coinage from collection in Croatia, Slovenia, Bosna \& Hercegovina, Narodni muzej Slovenije, Ljubljana, 1994.; Noel Malcolm, Povijest Bosne, Novi Liber, Zagreb - Dani, Sarajevo, 1995., str. 7-11; Ante Uglešrić, Nazočnost Istočnih Gota u jugoistočnoj Europi u svjetlu arheološke i povijesne izvorne grade, Doktorski rad, Sveučilište u Splitu, Filozofski fakultet u Zadru, Zadar, 1996.; NADA ZečEvić, Vizantija i Goti na Balkanu u IV i V veku, Srpska akademija nauka i umetnosti, Beograd, 2002. I tamo navedena literatura.

2 Usp. Konstantin Jirečen, Die Handelsstrassen und Bergwerke von Serbien und Bosnien während des Mittelalters. Historisch-geographische Studien, Gesellschaft der Wissenschaften, Prag, 1879.; [Mihailo Dinıć], ["Ekonomski razvitak Bosne u XIV. stoljeću"], u: Bogo Grafenauer - Dušan Perović - Jaroslav Šidak (red.), Historija naroda Jugoslavije, I., Školska knjiga, Zagreb, 1953., str. 572-577; Minailo J. Dinić, Za istoriju rudarstva u srednjovekovnoj Srbiji i Bosni, sv. I., Naučno delo, Beograd, 1955., sv. II., Naučno delo, Beograd, 1962.; Desanka Kovačević, Trgovina u srednjovjekovnoj Bosni, Naučno društvo Bosne i Hercegovine, Sarajevo, 1961.; Milenko S. Filipović, "Das Erbe der mittelalterlichen sächsischen Bergleute in den südslawischen Ländern", u: Südost-Forschungen, Band 22, München, 1963., str. 192-233; Sima ĆIr koviĆ, Istorija srednjovekovne bosanske države, Srpska književna zadruga, Beograd, 1964.; Adem Handžić, "Rudnici u Bosni u drugoj polovini XV. stoljeća", u: Prilozi za orijentalnu filologiju - Revue de philologie orientale, Vol. XXVI./1976., Sarajevo, 1978., str. 7-43; Desanka KovačEvićKouı́, Gradska naselja srednjovjekovne bosanske države, Veselin Masleša, Sarajevo, 1978.; Miklós Takács, "Sächsische Bergleute im mittelaterlichen Serbien und die 'sächsische Kirche' von Novo Brdo", u: Südost-Forschungen, Band 50, München, 1991., str. 31-60; N. Malcolm, Povijest Bosne, str. 31-32; Snežana BožAnić, "Rudarstvo u srednjovekovnoj Srbiji i Bosni", u: Spomenica Istorijskog arhiva Srem, br. 1, Sremska Mitrovica, 2002., str. 77-141; Desanka Kovačević-Kojić, Srednjovjekovna Srebrenica XIV - XV vijek, Srpska akademija nauka i umetnosti, Beograd, 2010. I tamo navedena literatura.

3 Usp. Franz Pfanner, Die Klostergeschichte von Mariastern, ersten Trappisten-Niederlassung in Bosnien, Kath. Preßverein, Graz, 1874. ili Franz Pfanner, Povijest samostana Marija Zvijezda 1869.-1874. Prvo naseljavanje trapista u Bosni, Župa Navještenja Blažene Djevice Marije, Velika Gorica, 2010.; Ivanko Vlašićak, Povijest trapinskog manastira "Marije zvijezde" kod Banje Luke, [Vlastita naklada], Virje, 1924.; Berislav Gavranović, Dolazak Trapista u Delibašino Selo kod Banja Luke i njihova djelatnost, [Vlastita naklada], Banja Luka, 1964.; Rudolf FATH, "Trappistenabtei 'Maria Stern' bei Banja Luka wird Zentrum religiöser Einkehr - und Besinnungstage für die Donauschwaben", u: Donauschwaben Kalender 1994, Aalen, 1993., str. 55-58; Anto Ćosić, 125. obljetnica trapističke opatije "Marija Zvijezda" u Banjaluci (1869-1994), [Vlastita naklada], Banja Luka, 1994.; Margareta Matijević, "Franz Pfanner (1825.-1909.) - ili kratko o doprinosu njemačkih trapista gospodarskom razvitku banjalučkog kraja", u: Godišnjak Njemačke narodnosne zajednice/VDG Jahrbuch 2002, Osijek, 2002., str. 279-286; NiKO- 
pacije, poslije 1878. Prve njemačke naseobine u Bosni i Hercegovini bile su Wind(t)horst/Nova Topola osnovan 1879. i Maglaj(ani) na Vrbasu/ Rudolfst(h)al/Adolfst(h)al/(Bosanski) Aleksandrovac osnovan 1880., kolonizirane na banjolučko područje doseljenicima, oko 500 obitelji, iz Porajnja, Šleske, Vestfalije, Braunschweiga, Hannovera i Oldenburga. ${ }^{4} \mathrm{Na}$ poziv trapista 1879. dolaze iz Austrije u Banju Luku redovnice Klanjateliice Krvi Kristove, koje unatoč po- četnom siromaštvu i jednostavnosti života podižu samostan Nazareth/ Nazaret te postupno šire djelovanje. Ubrzo osnivaju i prve zajednice u okolici: 1885. samostan u Rudofstalu/(Bosanski) Aleksandrovac, 1888. u Mittel-Wind(t)horstu/Nova Topola i drugdje, većinom u mjestima s doseljenim njemačkim kolonistima, u kojima otvaraju škole, dječja zabavišta, sirotišta i konvikte, ali primaju i djecu drugih etničkih skupina/nacionalnosti i vjeroispovijesti.

Laus Friedwagner, Marija Zvijezda i njezini trapisti - Mariastern und seine Trappisten, Trapistička opatija Marija Zvijezda, Banja Luka, 2009.; Branislav Teinović, Trapistička opatija Marija Zvijezda u Banjaluci (1869-2009). Katalog izložbe povodom 140 godina od osnivanja, postojanja i djelovanja, Muzej Republike Srpske, Banja Luka, 2009. I tamo navedeni izvori i literatura.

4 Usp. Franz Ostendorf - Johannes Ostendorf, Fünfzig Jahre Kolonie Nova Topola und Alexandrovac in Bosnien in Jugoslawien, Vechta in Oldenburg, 1930.; J. Scheben, "Eifeler Bauerntum in Bosnien", u: Bonifatiusblatt, Jg. 85, Nr. 6, Paderborn, 1936., str. 147-154; Carl Müller, "Niederrheinische Kolonisten in Bosnien", u: Die Heimat. Krefelder Jahrbuch. Zeitschrift für niederrheinische Kultur und Heimatpflege, Weihnachtsheft 1956, Krefeld, 1956., str. 125-128 ili Carl Müller, "Niederrheinische Kolonisten in Bosnien", u: Kalender für das Klever Land 1958, Kleve, 1957., str. 97-101 ili CarL MüLLER, "Niederrheinische Kolonisten in Bosnien", u: Heimatkalender Kreis Moers, Moers, 1959., str. 24-31; Helmut Rotthauwe Gen. Löns, "Neues Leben im Vrbastal, Bosnien wird von Leuten aus Millingen, Vehlingen, Haffen, Wesel, Rees, Haldern und Grietherbusch besiedelt", u: Heimatkalender Kreis Rees 1958., Rees, 1957., str. 48-49; CARL MüLleR, "Siedler von Eifel-Mittelrhein in Bosnien", u: Heimatjahrbuch Landkreis Ahrweiler, Rheinberg, 1960., str. 75-80; Friedrich G. Lamers, 65 Jahre Kolonien in Bosnien in Jugoslawien. Nova Topola (Windthorst) 1879-1944. Alexandrovac (Rudolfstal) 1880-1944, [Vlastita naklada], [St. Paul, Minnesota], 1970.; Friedrich G. Lamers, Zwei deutsche Kolonien in Bosnien. Erinnerungen an meine Heimat Windthorst, [Vlastita naklada], [St. Paul, Minnesota], 1978.; Martin Armgart - Gerda und Rolf Schulte - Wilfried Vogeler, "Auswanderer aus Essen nach Windhorst/Bosnien um 1879/80", u: Ostdeutsche Familienkunde, Band 39, Neustadt an der Aisch, 1991., str. 351-353 i 393-396; Paul-Josef Heister, "Niederrheinische Kolonisten in Bosnien", u: Mosaik. Zeitschrift für Familienforschung und Heimatkunde, Heft 2-3, Kleve, 2002., str. 9-10; Peter Schindler, 65 Jahre deutsche Kolonisten in Bosnien. Zwei geschlossene Kolonien Windthorst und Rudolfstal. Politische-Gemeinden [Nova Topola und Aleksandrovac] 1879-1944, [Vlastita naklada], [Hamburg], 2007.; AMIRA ŽMIRIć, Austrijski i njemački putopisi o Bosni i Hercegovini do 1941. godine, Besjeda, Banja Luka, 2012., str. 125-127. I tamo navedeni izvori i literatura.

5 Usp. Gedenkschrift zur 25-jährigen Jubelfeier der Schwestern der Kongregation von der. Anbetung des kostbaren Blutes Jesu Christi im Kloster Nazareth bei Banjaluka in Bosnien, 1879-1904, Druck Cordier, [Banja Luka], 1904.; 100 godina života i rada sestara Klanjateljica Krvi Kristove Provincije Zagreb, Sestre Klanjateljice Krvi Kristove, Banja Luka - Zagreb, 1979.; Duhovnost i povijest sestara Klanjateljica Krvi Kristove, Sestre Klanjateljice Krvi Kristove, Zagreb, 1982.; Flavija Šutić - Ines Kezić, S povjerenjem u Krv Jaganjčevu. Povijest hrvatske provincije sestara Klanjateljica Krvi Kristove, Klanjateljice Krvi 
Austrougarska je uprava poticala naseljavanje obrtnika, zemljoradnika i činovništva u Bosnu i Hercegovinu iz svojih pokrajina, Austrijanaca, Čeha, Slovaka, Mađara, Poljaka, Ukrajinaca, Hrvata, Slovenaca, Talijana, a napose Nijemaca iz Tirola i Njemačke. Doseljenici iz "naprednih zemalja" trebali su poslužiti kao uzor domaćim seljacima te tako pokrenuti modernizaciju Bosne i Hercegovine. U razdoblju od 1891. do 1905. godine kolonizirana je napose dolina rijeke Bosne. Među devedesetak erarnih kolonija, nastalih inicijativom vlade, koja je koloniste različitih narodnosti naseljavala na državnu zemlju, bilo je i desetak njemačkih s oko 1800 doseljenika iz Galicije. Većina kasnijih njemačkih kolonista u Bosnu i Hercegovinu došla je samopoticajno poslije 1885 . iz Banata, Bačke, Srijema i Slavonije. Slijede zatim, naposljetku, u skupinama po 5 do 30 obitelji, njemački kolonisti iz Bukovine, Galicije i Rusije. Znatnije njemačke naseobine bile su u Bosni i Hercegovini samo u banjolučkom, bosanskogradiškom, prnjavorskom i bijeljinskom kraju. Manje skupine Nijemaca nastanile su se i u industrijskim mjestima Drvaru, ${ }^{6}$ Zavidovićima, Žepču, Zenici, Tuzli te u Sarajevu, Mostaru, pa i drugim manjim mjestima. Nijemci su najzastupljeniji bili u banjolučkom i tuzlanskom kraju. Većina bosanskohercegovačkih Nijemaca živjela je u kolonijama, industrijskim/ radničkim, koje nisu bile stalne i zemljoradničkim/seoskim, koje su bile brojnije i stalnije. Slobodne njemačke zemljoradničke kolonije bile su Franz Josefsfeld/Schönborn/Petrovopolje/Novo Selo kod Bijeljine, Brezovopolje-Novi između Bijeljine i Brčkog, Božinci-Kolonija i Kalendarovci-Turski kod Dervente, Opsiečko (Njemačko), Wind(t)horst i Rudolfst(h)al/Adolfst(h)al kod Banje Luke, Ularice Nove kod Doboja, Trošelje kod Bosanske Gradiške. Erarne njemačke zemljorad ničke kolonije bile su Koraće, Kadar-Svilaj i Vrbovac-Svilaj kod Dervente, Schutzberg/Glogovac/Ukrinski Lug ${ }^{8}$ i Ši-

Kristove, Zagreb, 1984.; Ines Kezić, Hermina Gantert. Prva Klanjateljica Krvi Kristove u Bosni, Kršćanska sadašnjosti i Klanjateljice Krvi Kristove, Zagreb, 2004.; Cecilija Milković (prir.), Klanjateljice Krvi Kristove. Regija Zagreb, Klanjateljice Krvi Kristove, Zagreb, 2010.; Cecilija Milković - Cecilija Glibo - Vesna Abramović (prir.), Dan Klanjateljica. Spomen na proslavu 175. godišnjice nastanka Družbe Klanjateljica Krvi Kristove i 130. godišnjice djelovanja na ovim prostorima, Klanjateljice Krvi Kristove, Zagreb, 2010. I tamo navedeni izvori i literatura.

6 Usp. Friedrich Kühbauch, "Otto von Steinbeis und die Südostdeutschen. Merkwürdiges Spiel geschichtliger Zufälle", u: Donauschwaben Kalender 1963, Aalen, 1962., str. 61-68.

7 Usp. M.[atthias] Rometsch, 50 Jahre Petrovopolje in Bosnien, Novi Vrbas, 1936.; Fritz Hoffmann - Josef Zorn, Franz-Josefsfeld/Schönborn. Geschichte einer deutschen Gemeinde in Bosnien, Pannonia-Verlag, Freilassing, 1963.; Friedrich Hoffmann, "Vor 100 Jahren wurde Franzjosefsfeld (Schönborn) gegründet. Großes Wagnis für Franzfelder Familien, die 1885/86 nach Bosnien zogen", u: Donauschwäbische Familienkundliche Forschungsblätter, 12/1, Darmstadt, 1986., str. 2-7.

8 Usp. Ferdinand Sommer, Fern vom Land der Ahnen. Geschichte der deutschen evangelischen Gemeinde Schutzberg in Bosnien 1895-1942. Notvolle Heimkehr. Das Schicksal der Bosniendeutschen 1942-1960, [Vlastita naklada], Altenkirchen, Westerwald, 1960. 
bovska kod Prnjavora, ${ }^{9}$ Königsfeld/ Dubrava i Karlsdorf/Vrbaška kod Bosanske Gradiške, Vranovac i Prosara kod Bosanske Dubice, Branjevo na Drini ${ }^{10}$ i Dugopolje na Drini kod Zvornika. Sveukupno, u Bosni i Hercegovini je od potkraj 19. do početka 20. stoljeća osnovano pedesetak zemljoradničkih kolonija s oko 10.000 naseljenika, od kojih je bilo dvadesetak njemačkih kolonija s nekih 2000 naseljenika. ${ }^{11}$

9 Usp. Franz Oswald, Ortssippenbuch der Deutsch-Böhmen und Donauschwaben von Sibovska Bosnia von 1898 bis 1942 und deren Vorfahren in der Bukowina, Galizien und der Bačka, [Vlastita naklada], Graz, 1997., [Vlastita naklada], Graz, 2012.; SopHiE A. Welisch, "The Village of Sibovska in Bosnia and its German Bohemian Settlers from Galicia and Bukovina", u: The Bukovina Society of the Americas Newsletter, Vol. 17, No. 4, Ellis, Kansas, December 2007., str. 4-6.

10 Usp. Gustav Adolf Bayer, Und übrig blieb ein Johannisbrot-Baum. Branjevo an der Drina - Bosnien/Jugoslawien, [Vlastita naklada], Pfullingen, 1975.

11 Usp. Josef Heimfelsen, Die deutschen Kolonien in Bosnien, Gerold \& Co Buchhandlung, Sarajevo, 1911.; Joso LaKatoš, Narodna statistika, Vlastita naklada, Zagreb, 1914., str. 34-39; Hans Maier, Die deutschen Siedlungen in Bosnien, Ausland und Heimat Verlags-Aktiengesellschaft, Stuttgart, 1924.; KarL Hamm, "Bosnien und Herzegowina. Siedlungsgeschichte", u: Carl Petersen - Otto Scheel - Paul Hermann Ruth Hans Schwalm (Hrsg.), Handwörterbuch des Grenz - und Auslanddeutschtums, Band 1, Breslau, 1933., str. 497-498; Hermann Rüdiger, "Bosnien und Herzegowina. Wirtschaftlisches Leben der Deutschen", "1. Landdeutschtum", "2. Industrielles Deutschtum", u: Handwörterbuch des Grenz - und Auslanddeutschtums, Band 1, str. 500-501; H. Motschmann, "Aus deutschen Dörfern Bosniens", u: Wogeblatt, Jg. 4, Novi Sad, 1935., str. 10-12; R. Knopfmacher, "Die deutschen Siedlungen in Bosnien", u: Der Heimatkreis, Jg. 3, Heft 3, Klagenfurt, 1939., str. 13-14; Richard Klein, "Geschichte der deutschen Siedlungen in Bosnien", u: Deutsche Arbeit, Jg. 42, Heft 11, Berlin, 1942. str. 343-344; Georg Wagner, "Zwischen Batschka und Bosnien", u: Gerhardsbotte, Jg. 14, Nr. 7, Stuttgart, 1969., str. 3-4 ili Georg Wagner, "Zwischen Batschka und Bosnien", u: Hans Diplich - Hans Wolfram Hockel (Hrsg.), Wir Donauschwaben, Salzburg Akadem. Gemeinschaftsverl., Salzburg, 1950., str. 280-284; P. Pfaff, "Deutsche in Bosnien", u: Neuland, Jg. 6, Nr. 24, Salzburg - Freilassing, 1953., str. 7; F.[ERdinand] Sommer, "Auch in Bosnien gab es Deutsche", u: Mitteilungen für die Deutschen aus dem Donauraum, Jg. 6, Nr. 21, Karlsruhe, 1960., str. 1; Josef Müller, Syrmien-SlawonienBosnien. Verlorene Heimat deutscher Bauern, Pannonia-Verlag, Freilassing, 1961.; F.[RITz] Hoffmann, "Aus der Geschichte des Bosniendeutschtums. An - und Aussiedlung", u: Neuland, Jg. 15, Folge 51/52, Salzburg - Freilassing, 1962., str. 8; Ferdo Hauptmann, "Reguliranje zemljišnog posjeda u Bosni i Hercegovini i počeci naseljavanja stranih seljaka u doba austrougarske vladavine", u: Godišnjak Društva istoričara Bosne i Hercegovine, 16, Sarajevo, 1965., str. 151-171; Georg WiLD, "Deutsche Siedlungen in Syrmien, Slawonien und Bosnien", u: Südostdeutsches Archiv, Band 14, München, 1971., str. 144154; Fritz Hoffmann, Das Schicksal der Bosniendeutschen in 100 Jahren von 1878 bis 1978, O. Hartmann-Verlag, Sersheim, 1982.; Valentin Oberkersch, Die Deutschen in Syrmien, Slawonien, Kroatien und Bosnien. Geschichte einer deutschen Volksgruppe in Südosteuropa, Donauschwäbische Kulturstiftung, Stuttgart, 1989.; Goran BeUs RichemBERGH, "Nijemci u Bosni", u: Godišnjak Njemačke narodnosne zajednice/VDG Jahrbuch 1997, Osijek, 1997., str. 135-142; Ivan BalTa, "Njemačke kolonije u bosanskoj Posavini krajem 19. stoljeća", u: Godišnjak Njemačke narodnosne zajednice/VDG Jahrbuch 2004, Osijek, 2004., str. 211-217; Amila Kasumović, Njemački kolonisti u Bosni i Hercegovini u doba austro-ugarske uprave (1878.-1918.), Magistarski rad, Sveučilište u Zagrebu, Filozofski fakultet, Zagreb, 2008.; Amila Kasumović, "Modaliteti eksterne kolonizacije u Bosni i Hercegovini 1890-1914: Case study za njemačke erarne kolonije", u: Prilozi, 38, Sarajevo, 2009., str. 81-120; Goran Beus Richembergh, "Austro-njemački utjecaji u 
Najvećim dijelom njemački naseljenici u Bosni i Hercegovini bili su evangeličke vjeroispovijesti, ${ }^{12}$ a tek nešto više od četvrtine bili su rimokatolici. ${ }^{13} \mathrm{U}$ izvorima i literaturi različiti su navodi o broju njemačkih kolonija i broju njemačkih naseljenika u Bosnu i Hercegovinu. Prema brojidbenim pokazateljima 1910. godine (kriterij materinji jezik), u Bosni i Hercegovini bilo je 22.968 Nijemaca, ili 1,21 \% stanovništva. Od toga, nešto više od trećine bosanskohercegovačkih Nijemaca ži- vjelo je kao kolonisti u selima, a ostali u gradovima. ${ }^{14}$ No, mnogi od novopridošlih bili su državni činovnici, poslovni ljudi i vojnici, koji nisu namjeravali ostati u Bosni i Hercegovini. ${ }^{15}$

Potkraj 19. stoljeća sazrijevaju uvjeti za stvaranje nacionalne udruge Nijemaca u Bosni i Hercegovini, te je 1899 ., odnosno 1909., osnovan "Verein der Deutschen in Bosnien und Herzegowina" sa sjedištem u Sarajevu. ${ }^{16}$ Prije toga bosanskohercegovački Nijemci su se uglavnom okupljali u crkvenim

Bosni i Hercegovini od 1878. do 1918. godine", u: Godišnjak Njemačke zajednice/DG Jahrbuch 2010, Osijek, 2010., str. 317-334; Goran Beus Richembergh, Nijemci, Austrijanci i Hrvati, I. Prilozi za povijest njemačko-austrijske nacionalne manjine u Hrvatskoj i Bosñi i Hercegovini, SYNOPSIS i Njemačka zajednica - Zemaljska udruga Podunavskih Švaba u Hrvatskoj, Zagreb - Sarajevo, 2010.; Leni Perenčević, "'Pravo na zavičaj' - Identitet bosanskih Nijemaca u poslijeratnoj Njemačkoj", u: Husnija Kamberović (ur.), Identitet Bosne i Hercegovine kroz istoriju. Zbornik radova, 2, Institut za istoriju, Sarajevo, 2011., str. 157-161; Leni Perenčević, "'Fern vom Land der Ahnen' - Zur Identitätskonstruktion in bosniendeutschen Heimatbüchern", u: Elisabeth FendL Werner Mezger - Michael Prosser-Schell - Hans-Werner Retterath - Teresa VolK (Hrsg.), Jahrbuch für deutsche und osteuropäische Volkskunde, Band 51, Münster, 2010., str. 47-52. I tamo navedeni izvori i literatura.

12 Usp. Karl Hamm - Ferdinand Sommer, "Bosnien und Herzegowina. Kirchliches Leben der Deutschen", u: Handwörterbuch des Grenz - und Auslanddeutschtums, Band 1, str. 501-502; Georg WILD, Die Deutsche Evangelische Kirche in Jugoslawien 1918-1941, Verlag des Südostdeutschen Kulturwerkes, München, 1980.; KarL Sterlemann, Studien zur Kirchengeschichte der Reformierten Christlichen Kirche in Jugoslawien, Kroatien und Südungarn (von der Ansiedlungszeit bis 1944), [Vlastita naklada], Bad Neuheim, 1988., str. 144-149; Carl BethKe, "Deutsche 'Kolonisten' in Bosnien (1878-1918). Vorstellungswelten, Ideologie und Soziale Praxis in Quellen der Evangelischen Kirche", u: Zijad Senić (ur.), Bosna i Hercegovina u okviru Austro-Ugarske 1878-1918. Zbornik radova, Filozofski fakultet Sarajevo, Sarajevo, 2011., str. 235-266. I tamo navedeni izvori i literatura.

13 Usp. Josef Haltmayer, "Die katholischen Deutschen in Bosnien", u: Michael Lehmann - Josef Haltmayer (Hrsg.), Die katholischen Donauschwaben in der Doppelmonarchie 1867-1918. In Zeichen des Liberalismus, Verlag Buch und Kunst Kepplerhaus, Stuttgart, 1977., str. 497-523; Josef Haltmayer, "Die katholischen Deutschen in Bosnien und der Herzegowina 1918-1945", u: Michael Lehmann (Hrsg.), Die katholischen Donauschwaben in den Nachfolgestaaten 1918-1945. Im Zeichen des Nationalismus, Pannonia-Verlag, Freilassing, 1972., str. 341-355. I tamo navedeni izvori i literatura.

14 Usp. Rezultati popisa žiteljstva u Bosni i Hercegovini od 10. oktobra 1910, Sarajevo, 1912.; J. Lakatoš, Narodna statistika, str. 34-35; H. MaIER, Die deutschen Siedlungen in Bosnien, str. 28, 54; F. Hoffmann, Das Schicksal der Bosniendeutschen in 100 Jahren von 1878 bis 1978, str. 8.

15 N. Malcolm, Povijest Bosne, str. 195.

16 Usp. Dušan Biber, Nacizem in Nemci v Jugoslaviji 1933-1941, Cankarjeva založba, Ljubljana, 1966., str. 14; Valentin Oberkersch, "Syrmien - Slawonien Kroatien - 
društvima, pjevačkim društvima, tjelovježbenim društvima i čitaonicama. Početak Prvoga svjetskog rata 1914. prekinuo je udruživanje Nijemaca u Bosni i Hercegovini, a njegov ishod vratio je na početak pitanje položaja njemačke manjine u novonastaloj južnoslavenskoj državi. ${ }^{17}$

Raspadom Austro-Ugarske Monarhije pripadnici njemačke etničke skupine u jugoistočnoj Europi i u Kraljevini Srba, Hrvata i Slovenaca našli su se u novom položaju nacionalne manjine. Mirovne odredbe novonastalim su državama nametnule obvezu zaštite prava manjina, ali to je za oko dva milijuna Nijemaca europskoga jugoistoka, u Mađarskoj, Rumunjskoj i Kraljevini SHS, bila slaba utjeha. Nijemci su bili izloženi pritisku vlasti, što je dovelo i do iseljavanja. Najveći pad njemačkoga/austrijskoga stanovništva zabilježen je na područjima koja su pripadala austrijskoj državnoj upravi. Tako su se i iz Bosne i Hercegovine iselili oni čiji je boravak bio vezan uz austrougarska državna tijela. ${ }^{18}$

Njemačko manjinsko udruženje "Švapsko-njemački kulturni savez" ("Schwäbisch-Deutsche Kulturbund"), osnovano 1920. u Novom Sadu, u svojem je programu predviđa- lo djelatnosti na očuvanju i razvitku nacionalnoga identiteta, te unapređenje gospodarskoga napretka Nijemaca u Kraljevini SHS/Jugoslaviji. Pravila Kulturbunda sastavljena su po uzoru na pravila udruženja sudetskih Nijemaca i pravila srpskoga društva "Prosvjeta", koje je djelovalo u Bosni i Hercegovini u vrijeme Austro-Ugarske Monarhije. Na osnivačkoj skupštini Kulturbunda u Novom Sadu nazočili su uz predstavnike Nijemaca iz svih krajeva Kraljevine SHS i predstavnici bosanskohercegovačkih Nijemaca iz Banje Luke i Wind(t)horsta. Kulturbund u mjestima s većim brojem Nijemaca osniva mjesne saveze te su i u Bosni i Hercegovini, napose od sredine tridesetih godina 20. stoljeća, osnovani i mjesni savezi Kulturbunda (Königsfeld/Dubrava 1935., Wind(t) horst 1935., Vrbovac 1935., Zavidovići 1935., Brčko 1937., Šibovska 1937., Polje 1937., Franz-Ferdinandshöhe/ Ularice 1937., Rudolfstal 1940., Banja Luka 1940., Bosanska Gradiška 1940., Bosanski Šamac 1941., Teslić 1941.). Tridesetih godina 20. stoljeća Kulturbund je postao i djelatniji na otvaranju njemačkih škola, i u gradovima i selima osnivanju njemačkih čitaonica, i u područjima Kraljevine Jugoslavije koja je ranije zapostavljao,

Bosnien", u: Josef Volkmar Senz (Hrsg.), Donauschwäbische Siedlungsgebiete, Arbeitsgemeinschaft Donauschwäbischer Lehrer, München, 1974., str. 24; F. Hoffmann, Das Schicksal der Bosniendeutschen in 100 Jahren von 1878 bis 1978, str. 58; V. OBERKERSCH, Die Deutschen in Syrmien, Slawonien, Kroatien und Bosnien. Geschichte einer deutschen Volksgruppe in Südosteuropa, str. 108-109; C. Beтнкe, "Deutsche 'Kolonisten' in Bosnien (1878-1918). Vorstellungswelten, Ideologie und Soziale Praxis in Quellen der Evangelischen Kirche", str. 256.

17 Karl Hamm, "Politisches Leben [der Deutschen in Bosnien]", u: Handwörterbuch des Grenz - und Auslanddeutschtums, Band 1, str. 500; D. Biber, Nacizem in Nemci v Jugoslaviji 1933-1941, str. 14.

18 H. MaIer, Die deutschen Siedlungen in Bosnien, str. 28; D. Biber, Nacizem in Nemciv Jugoslaviji 1933-1941, str. 20, 31-32; F. HofFMAnn, Das Schicksal der Bosniendeutschen in 100 Jahren von 1878 bis 1978 , str. 8. 
što je bio slučaj s Bosnom i Hercegovinom. Tada su zbog jugoslavenskih gospodarskih probitaka uspostavljeni dobri odnosi s njemačkom državom te je tako otvoren i prostor za ubrzanu obnovu manjinskoga školstva njemačke skupine, što je pogodovalo sprječavanju ili, pak, usporavanju odnarođivanja jugoslavenskih Nijemaca. "Stranka Nijemaca u Kraljevini SHS" ("Partei der Deutschen in Königreiche SHS") osnovana 1922. godine, konzervativno usmjerena, nije imala znatnijega utjecaja na njemačko stanovništvo, i na izborima je osvajala tek pedesetak tisuća glasova. Najveći uspjeh stranke u kratkotrajnom djelovanju (zabranjena je uvođenjem šestojanuarske diktature 1929. godine, a kasnije nije obnovljena) bio je ulazak osmorice njezinih zastupnika u jugoslavensku skupštinu 1923. godine. Kulturbund je postao izrazito središte djelovanja njemačke manjine u Kraljevini SHS/Jugoslaviji, a svoja stajališta promiče preko glasila $D e-$ utsches Volksblatt. U Kraljevini SHS/ Jugoslaviji Kulturbund je nekoliko puta i zabranjivan i obnavljan, ovisno o politici koju su prema nacionalnim manjinama i Austriji i Njemačkoj (kasnije Njemačkom Reichu) vodile pojedine jugoslavenske vlade. Po svim obilježjima, i po suzdržljivosti većine Nijemaca u Kraljevini SHS/Jugoslaviji prema politici, ova se etnička skupina ni po čemu nije razlikovala od bilo koje druge etničke skupine. Elita njemačke manjine u Kraljevini SHS/ Jugoslaviji ubrzo uviđa da u državi, u kojoj je nacionalno pitanje od prvoga dana postalo trajnom okosnicom političkih sukoba, svoj program borbi za manjinska prava može ostvariti jedino u pogodbama s vodećim politič- kim snagama. Krilatica Kulturbunda "Vjernost domovini, vjernost svome narodu" ("Staatstreu und Volkstreu") naglašava namjeru da se prirodni problemi višenacionalne zajednice ne rješavaju zaoštravanjem, nego izbjegavanjem sporova. No, znatne i dalekosežne promjene nastaju s pojavom Obnoviteljskoga pokreta ("Kameradschaft für Erneuerungsbewegung des SDKB") radikalnoga usmjerenja među jugoslavenskim Nijemcima, koji sredinom tridesetih godina 20 . stoljeća počinje oponašati svoje uzore iz Njemačkoga Reicha. Začetnikom Obnoviteljskoga pokreta smatra se istaknuti član Kulturbunda dr. Jakob Awender iz Pančeva. Obnoviteljski pokret brzo se razvija, napose nakon što Branimir Altgayer 1936. godine u Osijeku osniva "Kulturno i dobrotvorno udruženje Nijemaca" ("Kultur und Wohlfahrtsvereinigung der Deutschen"). U njemačkoj narodnoj skupini dolazi do sudbinskoga raskola. Suočena s naglim rastom i pojačanom djelatnošću Obnoviteljskoga pokreta, koji svoja stajališta promiče preko glasila Volksruf, središnjica Kulturbunda 1936. godine donosi odluku o isključenju Obnovitelja iz Kulturbunda. Sukob se s rukovodstvom Kulturbunda prenosi na mjesne organizacije. Nakon dugotrajnih taktiziranja i političkoga manevriranja tijekom 1939. godine dolazi do prevage pristaša Obnovitelja u Kulturbundu i povlačenja posustaloga starog rukovodstva, lojalnog Kraljevini Jugoslaviji. Djelatnost i Kulturbunda i Obnovitelja na područjima gdje je njemačka manjina bila u procesu nacionalne asimilacije $s$ većinskim stanovništvom, imala je kulturni, a pojavom nacionalsocijalizma i poli- 
tički zadatak okupljanja Nijemaca i sprječavanja odnarođivanja njemačke manjine. Ne može se, međutim, poreći izravan utjecaj ustanova za unapređivanje položaja narodnosti u inozemstvu kojih je u Njemačkom Reichu bilo nekoliko. Napose je izrazita djelatnost Volksdeutsche Mittelstelle, ustanove Njemačkoga Reicha osnovane 1936. godine za koordinaciju rada s njemačkim narodnosnim manjinama $u$ inozemstvu, koja je umnogome određivala njihovu djelatnost, u skladu s politikom Njemačkoga Reicha. ${ }^{19}$

Nijemci su u Kraljevini SHS/Jugoslaviji, na bosanskohercegovačkom po- dručju bili najzastupljeniji u gradovima i okruzima Banja Luka, Bosanska Dubica, Bosanska Gradiška, Bijeljina, Brčko, Derventa, Gradačac, Mostar, Teslić, Travnik, Prijedor, Prnjavor, Sarajevo, Tuzla, Visoko, Zenica, Zvornik i Žepče. Prema brojidbenim pokazateljima (kriterij materinji jezik) Nijemaca u Bosni i Hercegovini 1921. bilo je 16.399 / 16.471, a 1931. bilo je 14.988 / 15.500 / 15.600 (prema različitim izračunima odnosno brojčanim iskazima). ${ }^{20}$

Međutim, postoje mišljenja da rezultati popisa iz 1921. i 1931. nisu realni za procjenu stvarnoga broja Nijemaca u Kraljevini SHS/Jugoslaviji, jer se

19 Usp. Ljubomir St. Kosier, Grossdeutschland und Jugoslawien (aus südslawischen Perspektive), Manzsche Verlagsbuchhandlung J. Klinkhard \& Co., Berlin - Wien, 1939.; DušAN Biber, Nacizem in Nemci v Jugoslaviji 1933-1941, Ljubljana, 1966.; Johann Wüscht, Beitrag zur Geschichte der Deutschen in Jugoslawien für den Zeitraum von 1934 bis 1944, [Vlastita naklada], Kehl am Rhein, 1966.; Josef Volkmar Senz, Das Schulwesen der Donauschwaben in Königreich Jugoslawien, Verlag des Südostdeutschen Kulturwerkes, München, 1969., str. 51-52, 78-129; Hans Rasimus, Als Fremde in Vaterland. Der Schwäbisch-deutsch Kulturbund und die ehemalige Deutsche Volksgruppe in Jugoslawien im Spiegel der Presse, Donauschwäbische Kulturstiftung, München, 1989.; V. OBERKersch, Die Deutschen in Syrmien, Slawonien, Kroatien und Bosnien. Geschichte einer deutschen Volksgruppe in Südosteuropa, str. 177-364; Valdis O. Lümans, Himmler's Auxiliaries. The Volksdeutsche Mittelstelle and the German national minorities of Europe, 19331945, The University of North Carolina Press, Chapel Hill and London, 1993.; Holm Sundhaussen, "Die Deutschen in Kroatien-Slavonien und Jugoslawien", u: GüNTER Schödl (Hrsg.), Deutsche Geschichte in Osten Europas. Land an der Donau, Siedler Verlag, Berlin, 1995., str. 315-335; Ljubodrag Dimić, Kulturna politika u Kraljevini Jugoslaviji 1918-1941., Treći deo, Politika i stvaralaštvo, Stubovi kulture, Beograd, 1997., str. 8-55; Vladimir Geiger, "Saslušanje Branimira Altgayera vođe Njemačke narodne skupine u Nezavisnoj Državi Hrvatskoj u Upravi državne bezbjednosti za Narodnu Republiku Hrvatsku 1949. godine", u: Casopis za suvremenu povijest, 3/1999., Zagreb, str. 578-584; Zoran Janjetović, Deca careva, pastorčad kraljeva. Nacionalne manjine u Jugoslaviji 1918-1941, Institut za noviju istoriju Srbije, Beograd, 2005.; Carl Bethke, Deutsche und ungarische Minderheiten in Kroatien und der Vojvodina 1918-1941, Harrassowitz Verlag, Wiesbaden, 2009.; Oskar Feldtänzer - Georg Wildmann, "Die Donauschwaben in Jugoslawien 1918-1944", u: Georg Wildmann, Donauschwäbische Geschichte, Band III, Die Tragödie der Selbstbehauptung im Wirkfeld des Nationalismus der Nachfolgestaaten 1918-1944, Donauschwäbische Kulturstiftung, München, 2010., str. 471-605. I tamo navedena literatura.

20 Usp. H. Maier, Die deutschen Siedlungen in Bosnien, str. 28; Definitivni rezultati popisa stanovništva od 31 januara 1921 god. Kraljevina Jugoslavija, Sarajevo, 1932.; Prethodni rezultati popisa stanovnistva od 31 marta 1931 godine u Kraljevini Jugoslaviji, Beograd, 1931.; W.[Illelm] Winkler, "Bosnien und Herzegowina. Bevölkerungsstatistik", u: 
dio njih iz raznih razloga, posebice gospodarskih i političkih, denacionalizirao u Slovence, Hrvate, Mađare, Srbe i druge. Iako je u Kraljevini SHS/Jugoslaviji uslijedilo razdoblje pada prirodnoga rasta njemačkoga stanovništva, dio se asimiliranih do početka Drugoga svjetskog rata opet očitovao kao Nijemci, što se vezuje uz djelovanje Kulturbunda i Obnovitelja, ali i krupnih promjena u domaćim i međunarodnim političkim odnosima. $^{21}$

Nakon napada Njemačkoga Reicha na Kraljevinu Jugoslaviju i uspostave Nezavisne Države Hrvatske u travnju 1941. dolazi do potpuno novih i iz- mijenjenih okolnosti i za pripadnike njemačke manjine u Bosni i Hercegovini. Nijemci u NDH ustrojeni su u Njemačku narodnu skupinu (Die Deutsche Volksgruppe) po strogo vodstvenim načelima (Führerprinzip), po uzoru na Njemački Reich. Pripadnicima njemačke narodne skupine $\mathrm{u}$ $\mathrm{NDH}$ zakonski je zajamčena ravnopravnost s hrvatskim narodom. ${ }^{22}$

Nijemci su u Bosni i Hercegovini početkom Drugoga svjetskog rata bili najzastupljeniji u gradovima, odnosno okruzima Bosanska Gradiška, Sarajevo, Bijeljina, Prnjavor, Derventa, Banja Luka, Zenica, Žepče, Brčko, Tuzla, Doboj, Teslić, Pri-

Handwörterbuch des Grenz- und Auslanddeutschtums, Band 1, str. 496-497; Gliederung der Bevölkerung des ehemaligen Jugoslawien nach Muttersprache und Konfession nach den unveröffentlichten Angaben der Zählung von 1931, Publikationsstelle, Wien, 1943.; D. Biber, Nacizem in Nemci v Jugoslaviji 1933-1941, str. 20; F. Hoffmann, Das Schicksal der Bosniendeutschen in 100 Jahren von 1878 bis 1978, str. 8; H. Rasimus, Als Fremde in Vaterland. Der Schwäbisch-deutsch Kulturbund und die ehemalige Deutsche Volksgruppe in Jugoslawien im Spiegel der Presse, str. 574, 582-583, 584-585, 588-589.

21 Usp. Zdravko Krnić - Srećko Ljubljanović - Cvetko Tomljanović, "Neki podaci o organizaciji i radu Njemačke narodne skupine u NDH", u: Zbornik. Historijski institut Slavonije, 1, Slavonski Brod, 1963., str. 7-13; D. Biber, Nacizem in Nemci v Jugoslaviji 1933-1941, str. 16-17; Michael Hottinger [Anton Scherer], "Die Donauschwaben in Jugoslawien", u: Die Weg in die neue Heimat. Die Volksdeutschen in der Steiremark, Leopold Stocker Verlag, Graz - Stuttgart, 1988., str. 112-113, 128 ili ANTON Scherer, "Podunavski Švabe u Jugoslaviji", u: Anton Scherer - Manfred Straka, Kratka povijest podunavskih NijemacalAbriss zur Geschichte der Donauschwaben, Pan-liber, Osijek Zagreb - Split, Graz - Stuttgart, 1999., str. 31-32, 50/99-101, 120-121; V. OBerkersch, Die Deutschen in Syrmien, Slawonien, Kroatien und Bosnien. Geschichte einer deutschen Volksgruppe in Südosteuropa, str. 496-497; Z. JanjeTović, Deca careva, pastorčad kraljeva. Nacionalne manjine u Jugoslaviji 1918-1941, str. 62-82. I tamo navedena literatura.

22 Usp. Bogumil Von Andrašević, "Die deutschen Siedlungen in Mittel-Kroatien", u: Jahrbuch des Osteuropa-Instituts zu Breslau, Breslau, 1942., str. 217-269; Hugo Grothe, "Die Volksdeutschen Bosniens", u: Archiv für Wanderungswesen und Auslandskunde, Jg. 8, Heft 3, Leipzig, 1942., str. 102-103; Wilhelm Sattlen, Die deutsche Volksgruppe im unabhängigen Staat Kroatien. Ein Buch vom Deutschtum in Slawonien, Syrmien und Bosnien, Steirische Verlagsanstalt, Graz, 1943.; Z. Krnić - S. Ljubljanović - C. ToMLJANOvić, "Neki podaci o organizaciji i radu Njemačke narodne skupine u NDH", str. 7-70; Zdravko Krnić, Njemačka narodna skupina u NDH, Doktorski rad, Univerzitet u Sarajevu, Filozofski fakultet, Sarajevo, 1972.; Tomislav IšEk, "Djelatnost Kulturbunda i Folksdojčera", u: Sarajevo u revoluciji, Tom drugi, Komunistička partija Jugoslavije u pripremama i organizaciji ustanka, Istorijski arhiv, Sarajevo, 1977., str. 284-291; Milan Vukmanović, "Neka pitanja o obrazovanju i djelovanju ustaškog stožera za takozvanu Bosansku Hrvatsku i povjereništva za Vrbasku banovinu u Banjaluci od aprila do avgu- 
jedor, Gradačac, Zvornik i Jajce. ${ }^{23}$ Različiti su, a i oprječni, navodi o broju Nijemaca u Nezavisnoj Državi Hrvatskoj, pa i o broju Nijemaca u Bosni i Hercegovini 1941. odnosno u vrijeme Drugoga svjetskog rata. Navodi o broju Nijemaca u Bosni i Hercegovini u širokom su rasponu od 16.000 do 23.000. Početkom Drugoga svjetskog rata, prema podatcima njemačke narodne skupine u NDH potkraj 1941., na području Bosne i Hercegovine bilo je 23.267 Nijemaca, ${ }^{24}$ a brojku od 23.000 Nijemaca u Bosni i Hercegovini u svojim izvješćima spominje i Ministarstvo vanjskih poslova Njemačko- ga Reicha i Poslanstvo Njemačkoga Reicha u Zagrebu, u ljeto 1942.25 No, prema povjesničaru W. Sattleru, koji se 1943 . poziva na podatke njemačke narodne skupine u NDH, na području Bosne i Hercegovine potkraj 1941. bilo je 19.900 Nijemaca. ${ }^{26}$ Različiti su i poslijeratni njemački/ folksdojčerski navodi o broju Nijemaca u Bosni i Hercegovini u vrijeme Drugoga svjetskog rata. Prema L. Schumacheru, koji se izračunima/ procjenama oslanja na rezultate popisa iz 1931., Nijemaca je u Bosni i Hercegovini bilo 1941./1944. oko $16.000 .{ }^{27}$ Povjesničar V. Oberkersch, pak, broj Nijemaca u Bosni i Herce-

sta 1941. godine", u: Istorijski zbornik. Institut za istoriju u Banjaluci, br. 5, Banja Luka, 1984., str. 90-94; V. Oberkersch, Die Deutschen in Syrmien, Slawonien, Kroatien und Bosnien. Geschichte einer deutschen Volksgruppe in Südosteuropa, str. 367-461; Leidensweg der Deutschen im kommunistischen Jugoslawien, Band I, Ortsberichte über die Verbrechen an den Deutschen durch das Tito-Regime in der Zeit von 1944-1948, Donauschwäbische Kulturstiftung, München - Sindelfingen, 1991., str. 810-829 ili Weißbuch der Deutschen aus Jugoslawien. Ortsberichte 1944-1948, Universitas, München, 1991., str. 810-829; H. Sundhaussen, "Die Deutschen in Kroatien-Slavonien und Jugoslawien", str. 335-342; V. Geiger, "Saslušanje Branimira Altgayera vođe Njemačke narodne skupine u Nezavisnoj Državi Hrvatskoj u Upravi državne bezbjednosti za Narodnu Republiku Hrvatsku 1949. godine", str. 596-605; Mario JAREB, "The German Ethnic Group in the Independent State of Croatia from 1941 to 1945", u: Review of Croatian History, Vol. III., No. 1, Zagreb, 2007., str. 201-217; Zija Sulejmanpašić, Više nas nisu hapsili 1931.-1950., Udruženje za zaštitu tekovina borbe za Bosnu i Hercegovinu, Sarajevo, 2012., str. 87-92, 149-151. I tamo navedena literatura.

23 Muzej Slavonije, Osijek, Povijesni odjel, fasc. Službeni listovi, odluke, naređenja 1944. g., "Zahl der deutschen Bevölkerung auf Grund der Ergebnisses der Bestandsaufnahme von 11.12.1941. nach Grossgespanschaften und Verwaltungsbezirken im ua. Staate Kroatien".

24 Isto.

25 HrVATSKI DRŽAVNi ARHIV, ZAGREB (dalje: HDA), Zbirka mikrofilmova, Nacionalni arhiv Washington, Njemački dokumenti - D - 64, snimka 671-673, [Ribbentrop - Kasche o preseljenju folksdojčera iz Bosne u Njemački Reich, srpanj 1942.]; NADA KIsıć Kolanović, Mladen Lorković, ministar urotnik, Golden Marketing, Zagreb, 1998., str. 210; Nada Kisić Kolanović, "Siegfried Kasche: njemački pogled na Hrvatsku 1941. godine", u: Časopis za suvremenu povijest, 3/2011., Zagreb, str. 784.

26 W. Sattler, Die deutsche Volksgruppe im unabhängigen Staat Kroatien. Ein Buch vom Deutschtum in Slawonien, Syrmien und Bosnien, str. 36.

27 Ludwig Schumacher, "Vertreibungsverluste der Deutschen in Jugoslawien im Spiegel der Statistik", u: Jahrbuch der Deutschen aus Jugoslawien. Volkskalender 1960, Stuttgart, 1960., str. 125. 
govini 1941. zaokružuje na $20.000 .^{28}$ Prema F. Hoffmannu 1942./1944. bilo je 18.367 Nijemaca, ${ }^{29}$ a prema K. Weberu 1941. bilo je $21.000 \mathrm{Ni}$ jemaca u Bosni i Hercegovini. No, procjena o 21.000 Nijemaca u Bosni i Hercegovini u vrijeme Drugoga svjetskog rata uglavnom je prihvaćena i navođena u njemačkoj/folksdojčerskoj historiografiji i publicistici. ${ }^{30}$ Znatno su različiti i izračuni/procjene u srpskoj i hrvatskoj literaturi o ljudskim gubitcima Jugoslavije u Drugome svjetskom ratu, koliko je 1941. bilo Nijemaca u Bosni i Hercegovini. Početkom Drugoga svjetskog rata 1941. Nijemaca je u Bosni i Hercegovini bilo prema izračunu/ procjeni B. Kočovića, ${ }^{31}$ kao i prema izračunu/procjeni Ž. Đorđevića ${ }^{32}$ 18.000, a prema izračunu/procjeni V. Žerjavića $16.000 .{ }^{33}$ No, L. Schu- macher, B. Kočović, V. Žerjavić i Ž. Đorđević zanemarili su mišljenja da rezultati popisa iz 1931. godine nisu realni za procjenu stvarnoga broja Nijemaca u Kraljevini Jugoslaviji, pa ni u Bosni i Hercegovini, a i za procjenu stvarnoga broja Nijemaca 1941., jer se dio njih iz raznih razloga, posebice gospodarskih i političkih, "asimilirao", odnosno drukčije iskazivao. Naime, dio se njih do početka Drugoga svjetskog rata opet očitovao kao Nijemci, što se vezuje uz djelovanje Kulturbunda i Obnovitelja, tridesetih godina 20. stoljeća, ali i krupnih promjena na domaćem i međunarodnom političkom planu. Uz to, popise stanovništva u Kraljevini SHS/Jugoslaviji, napose popis iz 1931. godine mnogobrojni, pa i Nijemci, kao odraz stvarne nacionalne/ etničke strukture stanovništva (na

28 Valentin Oberkersch, "Die Umsiedlung der Bosniendeutschen", u: Donauschwaben Kalender 1988, Aalen, 1987., str. 65.

29 Usp. F. Hoffmann, Das Schicksal der Bosniendeutschen in 100 Jahren von 1878 bis 1978 , str. 72.

30 Usp. Leidensweg der Deutschen im kommunistischen Jugoslawien, Band III, Erschießungen-Vernichtungslager-Kinderschicksale in der Zeit von 1944 bis 1948, Donauschwäbische Kulturstiftung, München - Sindelfingen, 1995., str. 897, 941 ili Weißbuch der Deutschen aus Jugoslawien. Erschießungen - Vernichtungslager - Kinderschicksale in der Zeit von 1944 1948, Universitas, München, 1995., str. 897, 941; Karl Weber, "Bevölkerung und Verluste. Die demographische Erfassung der Jugoslawiendeutschen", u: Donauschwaben Kalender 1996, Aalen, 1995., str. 72; Verbrechen an den Deutschen in Jugoslawien 19441948. Die Stationen eines Völkermords, Donauschwäbische Kulturstiftung, München, 1998., str. 291; O. FeldtänZer - G. Wildmann, "Die Donauschwaben in Jugoslawien 1918-1944", str. 478.

31 Usp. Bogoljub Kočović, Žrtve Drugog svetskog rata u Jugoslaviji, London, 1985., str. 174, Svjetlost, Sarajevo, 1990., str. 164 ili Bogoljub Kočović, Sahrana jednog mita. Žrtve Drugog svetskog rata u Jugoslaviji, Otkrovenje, Beograd, 2005., str. 164.

32 Usp. Žıvotije ĐorĐević, Gubici stanovništva Jugoslavije u Drugom svetskom ratu, ABCGrafika, Beograd, 1997., str. 158, 161.

33 Usp. Vladimir ŽErJavić, Gubici stanovništva Jugoslavije u drugom svjetskom ratu, Jugoslavensko viktimološko društvo, Zagreb, 1989., str. 36; Vladimir ŽERJAVIĆ, Opsesije i megalomanije oko Jasenovca i Bleiburga. Gubici stanovništva Jugoslavije u drugom svjetskom ratu, Globus, Zagreb, 1992., str. 133; Vladimir Žerjavić, Population losses in Yugoslavia 1941-1945, Dom i Svijet \& Hrvatski institut za povijest, Zagreb, 1997., str. 135; Vladimir Žerjavić, Pertes de la population en Yougoslavie 1941-1945, Dom i Svijet \& Hrvatski institut za povijest, Zagreb, 1997., str. 144. 
temelju materinjeg jezika) ne prihvaćaju, jer su bile moguće popisne manipulacije. Nedvojbeno je da je 1941. godine, odnosno u vrijeme $\mathrm{NDH}$, broj bosanskohercegovačkih Nijemaca bio drukčiji i veći od Kočovićevih i napose Schumacherovih i Žerjavićevih izračuna/procjena.

Tijekom Drugoga svjetskog rata pripadnici njemačke narodne skupine u $\mathrm{NDH}$ unovačeni su u oružane snage NDH (Deutschen Jägerbataillons/ Njemačke lovačke bojne, u sklopu Domobranstva i Einsatzstaffel der Deutschen Mannschaft, u sklopu Ustaške vojnice) i borili su se na području $\mathrm{NDH}$, ili su unovačeni u oružane snage Njemačkog Reicha (Wehrmacht i Waffen-SS) i borili su se na području NDH i na Balkanu ili na nekoj od europskih bojišnica, najviše na Istoku. U sklopu vojnih i poluvojnih postrojbi NDH i Njemačkog Reicha bosanskohercegovački Nijemci uključeni su u borbena djelovanja protiv ustanika, partizanskoga pokreta, ali i četnika (ponajprije kao pripadnici Deutschen Jägerbataillons i Einsatzstaffel DM, zatim napose 7. SS-divizija "Prinz Eugen"), te u obranu od ustanika sve ugroženijih svojih naseobina i na području Bosne i Hercegovine (Ortsschutz, zatim Heimatwacht der Deutschen Volksgruppe im Unabhängigen Staate Kroatien). Nakon uključivanja postrojbi Einsatzstaffela DM u sastav pojedinih operativnih dijelova Wehrmachta i Waffen SS-a, stalne vojne posade ostale su u najugroženijim njemačkim naseljima. Pripadnici Njemačke narodne skupine od 14 do 65 godina, koji nisu bili unovačeni u vojne postrojbe, bili su još od travanjskih dana 1941. uključeni u Mjesne zaštite (Ortsschutz) kao poluvojne postrojbe, ali bez nekoga jačeg provedenog ustroja, čiji je zadatak bio stražarenje i ophodnja u mjestima s njemačkim stanovništvom i obrana od ustanika. ${ }^{34}$

34 Usp. W. Sattler, Die deutsche Volksgruppe im unabhängigen Staat Kroatien. Ein Buch vom Deutschtum in Slawonien, Syrmien und Bosnien, str. 64, 100-104; Dokumentation der Vertreibung der Deutschen aus Ost-Mitteleuropa, Band V, Das Schicksal der Deutschen in Jugoslawien, Herausgegeben vom ehemaligen Bundesministerium für Vertriebene, Flüchtlinge und Kriegsgeschädigte, Düsseldorf, 1961., München, 1984., Augsburg, 1994., München, 2004., str. 50E-54E, 72E-75E; J. WüsCHт, Beitrag zur Geschichte der Deutschen in Jugoslawien für den Zeitraum von 1934 bis 1944, str. 88-107; Z. KRnIĆ - S. Ljubljanović - C. Tomljanović, "Neki podaci o organizaciji i radu Njemačke narodne skupine u NDH", str. 26-40; Holm Sundhaussen, "Zur Geschichte der WaffenSS in Kroatien 1941-1945", u: Südost-Forschungen, Band XXX, München, 1971., str. 176-196; Mladen Colić, Takozvana Nezavisna Država Hrvatska 1941., Delta-pres, Beograd, 1973., str. 295-298; Antun Miletić, "Vojne formacije Folksdojčera u borbi protiv NOP-a na nemačkoj okupiranoj teritoriji NDH (1941-1944)", u: Zbornik. Historijski institut Slavonije i Baranje, 11, Slavonski Brod, 1974., str. 91-115 ili AnTuN Miletić, "The Volksdeutschers of Bosnia, Slavonia and Srem Regions in the struggle against the People's Liberation Movement (1941-1944)", u: The Third Reich and Yugoslavia 1933-1945, Institut za savremenu istoriju, Beograd, 1977., str. 559-603; ОтTO Kumm, Vorwärts, Prinz Eugen! Geschichte der 7. SS-Freiwilligen-Division "Prinz Eugen", Munin-Verlag, Coburg, 1978.; Отто Kuмм, 7. SS-Gebirgs-Division "Prinz Eugen" im Bild, Munin-Verlag, Coburg, 1983.; V. Oberkersch, Die Deutschen in Syrmien, Slawonien, Kroatien und Bosnien. Geschichte einer deutschen Volksgruppe in Südosteuropa, str. 398-421; Friedrich Küнbauch, "Zur Geschichte des Deutschen Jägerbataillons in Kroatien 1941-1943", u: Donauschwaben Kalender 1993, Aalen, 1992., str. 55-58; 
Zbog ugroženosti i nesigurnosti njemačkih naselja i stanovništva u NDH, napose u Bosni i Hercegovini, koju su izazvali ustanici, partizani - Narodnooslobodilačka vojska i partizanski odredi Jugoslavije, a i četnici - Jugoslovenska vojska u Otadžbini, od početka Drugoga svjetskog rata dolazi do njihova preseljavanja i iseljavanja. Naime, zaštita i obrana njemačkih naselja u Bosni i Hercegovini, povjerena ponajprije mjesnim zaštitama (Ortsschutz), najčešće nije mogla zaštititi svoja naselja, ljude i imovinu, pa ni nakon što je u njihovu zaštitu uključen Einsatzstaffel DM. Prva preseljavanja njemačkoga stanovništva u NDH bila su potkraj 1941. i početkom 1942. iz najugroženijih naselja u Potkozarju, Lici, Kordunu, Banovini i sjeverozapadnoj Bosni, najprije na sigurnije područje zapadne Slavonije, a zatim početkom 1942. u Srijem. Zbog sve veće ugroženosti i potrebe preseljavanja, tijekom 1942. osnivaju se komisije i uredi za preseljavanje pripadnika njemačke narodne skupine u NDH. U sklopu Poslanstva Njemačkoga Reicha u Zagrebu ustrojeno je Povjerenstvo za preseljavanje pripadnika njemačke narodne skupine iz sjeverozapadne Bosne (Treuehänder für Umsiedlung der Bosnien-Deutschen). Prva mjesta u Bosni i Hercegovini koja su pripadnici njemačke narodne skupine napustili u prosincu 1941. bili su Königsfeld/Dubrava i Karlsdorf/Vrbaška kod Bosanske Gradiške. Preselili su se privremeno u Staru Gradišku i na područje Nove Gradiške. Tijekom siječnja 1942. većina ih je preseljena na područje Inđije, u Srijem. Potkraj 1942., uza znatne materijalne napore i uza zaštitu njemačkih postrojbi u sklopu Oružanih snaga NDH, dolazi do iseljavanja, pretežito u Njemački Reich, bosanskohercegovačkih Nijemaca, koji su bili najugroženiji djelovanjima napose partizanskoga, ali i četničkoga pokreta. Ugovor vlada NDH i Njemačkoga Reicha o iseljavanju Nijemaca $s$ pojedinih područja NDH (Vereinbarung zwischen der Deutschen Regierung und der Regierung des Unabhängigen Staates Kroatien über die Umsiedlung von Angehörigen des deutschen Volkstums aus bestimmten Gebieten des Unabhängigen Staates Kroatien in das Deutsche Reich), koji su bili najizloženiji partizanskim napadima, odnosno gotovo svih Nijemaca iz Bosne i Hercegovine izuzev onih iz Wind(t)horsta, Adolfstala i Trošelja kod Bosanske Gradiške i Brčkog te također iseljavanje Ni-

\footnotetext{
Friedrich KüHbauch, "Zur Wehrpflicht der Volksdeutschen in Kroatien während des Zweiten Weltkrieges", u: Donauschwaben Kalender 1994, Aalen, 1993., str. 59-61; VLADimir Geiger, "Vojne i poluvojne postrojbe Njemačke Narodne Skupine u Nezavisnoj Državi Hrvatskoj", u: Godišnjak Njemačke narodnosne zajednice/VDG Jahrbuch 1995, Zagreb, 1995., str. 159-165; Enver RedžIć, Bosna i Hercegovina u Drugom svjetskom ratu, Grafičko-izdavačka kuća d.d. i ANUBiH, Sarajevo, 1998., str. 54; V. Geiger, "Saslušanje Branimira Altgayera vođe Njemačke narodne skupine u Nezavisnoj Državi Hrvatskoj u Upravi državne bezbjednosti za Narodnu Republiku Hrvatsku 1949. godine", str. 605-612, 628-629; Anna M. Wittmann, "Mutiny in the Balkans: Chroat Volksdeutsche, the Waffen-SS and Motherhood", u: East European Quaterly, Vol. XXXVI., No. 3, Boulder, Colorado, 2002., str. 254-279; Thomas Casagrande, Die volksdeutsche SS-Division "Prinz Eugen". Die Banater Schwaben und die nationalsozialistischen Kriegsverbrechen, Campus Verlag, Frankfurt, 2003. I tamo navedena literatura.
} 
jemaca iz pojedinih gradova i sela $u$ Hrvatskoj, potpisan je u Zagrebu 30. rujna 1942. Navodi o broju Nijemaca iseljenih iz Bosne i Hercegovine potkraj 1942. u širokom su rasponu od 15.000 do 23.000 , a ponajprije izvori, pa i literatura najčešće navode 17.000 do 18.000. Iz bosanskohercegovačkih gradova i sela trebalo je iseliti prema službenim navodima 17.363 Nijemaca (Bosanska Krupa, Prijedor, Karlsdorf/Vrbaška, Bosanska Gradiška, Banja Luka, Prnjavor, Glogovac, Teslić, Derventa, Koraće, Bosanski Brod, Bosanski Šamac, Gradačac, Doboj, Tuzla, Bijeljina, Schönborn/ Novo Selo/Petrovo Polje, Zavidovići, Zenica, Jajce, Sarajevo, Mostar i dr.). U izvorima i literaturi navode se i nešto veće brojke, naime da se nakon ugovora NDH i Njemačkog Reicha u rujnu 1942. o iseljavanju Nijemaca $s$ pojedinih područja NDH, ponajprije iz Bosne i Hercegovine, u vremenu od 6. listopada do 22. studenoga 1942., ukupno iselilo 17.904, odnosno 18.360 ili pak 18.370 Nijemaca. $\mathrm{U}$ ove su ukupne brojeve iseljenih u Njemački Reich uključeni i bosanskohercegovački Nijemci preseljeni u Slavoniju i Srijem potkraj 1941. i početkom 1942., a dijelom i Nijemci iseljeni iz Hrvatske. Naime, potkraj 1942. i iz nekih hrvatskih gradova i sela iselilo se oko 2500 Nijemaca. Najveći broj bosanskohercegovačkih Nijemaca preseljen je 1942. u Njemački Reich, odnosno na područje Litzmannstadta (Lodź) u okupiranoj Poljskoj. Nakon naseljavanja u nova područja Njemačkoga Reicha ovi su iseljenici dobivali državljanstvo Njemačkoga Reicha, ali i izgubili pravo povratka u zavičaj. ${ }^{35}$

35 Usp. HDA, Zbirka mikrofilmova, Nacionalni arhiv Washington, Njemački dokumenti - D - 64, snimka 671-673 [Ribbentrop - Kasche o preseljenju folksdojčera iz Bosne u Njemački Reich, srpanj 1942.]; HDA, Ministarstvo vanjskih poslova Nezavisne Države Hrvatske, kut. 3, Utanačenje između vlade NDH i Njemačke vlade o selidbi pripadnika njemačke narodnosti sa stanovitih područja NDH u Njemački Reich od 30. rujna 1942.; Bundesarchiv, Koblenz, Akten R 59, Aktenband 400 und 402; Ottilie HeuChert, "Umsiedlung der Bosnien-Deutschen", u: Deutschtum im Ausland, Jg. 20, Heft 1/2, Stuttgart, 1943., str. 31-34; Ludwig Lutz, "Umsiedlung 1942.", u: Deutschtum im Ausland, Jg. 26, Heft 5/6, Stuttgart, 1943., str. 110-111; Richard Klein, "Die Umsiedlung des Deutschtums Bosniens", u: Nation und Staat, Jg. 16, Heft 4/5, Wien, 1943. , str. 120-123; Ferdinand Sakar, "Umsiedlung Bosniens", u: Deutsche Arbeit, Jg. 43, Heft 2, Berlin, 1943., str. 55-60; W. SATTLER, Die deutsche Volksgruppe im unabhängigen Staat Kroatien. Ein Buch vom Deutschtum in Slawonien, Syrmien und Bosnien, str. 66-67; Leopold Egger, "Akten Umsiedlung aus Bosnien, Serbien, Gottschee, Untersteiermark und Krain", u: Neuland, Jg. 6, Nr. 29, Salzburg - Freilassing, 1953., str. 4; Theodor Bierschenk, "Zahlen über die währen des 2. Weltkrieges umgesiedelten deutschen Volksgruppenangehörigen", u: Zeitschrift für Ostforschung, Jg. 3, Marburg, 1954., str. 80-83; [LEOPOLD] EGGER, "LAG-Unterlagen für Gottscheer und Bosniendeutsche", u: Neuland, Jg. 9, Folge 50, Salzburg - Freilassing, 1956., str. 1; L. Schumacher, "Vertreibungsverluste der Deutschen in Jugoslawien im Spiegel der Statistik", str. 115, 128-130; F. Sommer, Fern vom Land der Ahnen. Geschichte der deutschen evangelischen Gemeinde Schutzberg in Bosnien 1895-1942. Notvolle Heimkehr. Das Schicksal der Bosniendeutschen 1942-1960, str. 131-137; Dokumentation der Vertreibung der Deutschen aus Ost-Mitteleuropa, Band V, Das Schicksal der Deutschen in Jugoslawien, Düsseldorf, 1961., München, 1984., Augsburg, 1994., München, 2004., str. 83E-85E; Z. Krnić - S. Ljubljanović - C. Tomljanović, "Neki podaci o organizaciji i radu Njemačke narodne skupine u NDH", str. 27; J. Wüscht, Beitrag zur Geschichte der Deutschen in Jugoslawien für den 
Prema proglasu Branimira Altgayera, vođe njemačke narodne skupine u NDH, iz rujna 1942., oni bosanskohercegovački Nijemci koji se ne odazovu pozivu za "dobrovoljno" iseljavanje ("povratku u Domovinu", kako su to nazivale vlade Njemačkoga Reicha i NDH) i ostanu svojevoljno u mjestima NDH iz kojih će se Nijemci iseliti i gdje prestaju i raspuštaju se sve njemačke ustanove, "gubi svaku mogućnost za zaštitu i brigu njemačkog naroda i Reicha". ${ }^{36}$

Navodi o broju Nijemaca iseljenih iz Bosne i Hercegovine tijekom 1943. i do potkraj 1944. različiti su, i mogli bi iznositi oko 2000 do 3000 osoba. Tijekom 1943., i napose od potkraj

Zeitraum von 1934 bis 1944, str. 112-113; ZDRAVKo KRNIĆ, "O iseljavanju pripadnika Njemačke narodne skupine (Volksdeutschera) iz NDH za vrijeme II svjetskog rata", u: Zbornik. Historijski institut Slavonije, 4, Slavonski Brod, 1966., str. 77-80; ANTUN MiLETIĆ, "Preseljenje i evakuacija Folksdojčera iz Srijema i Slavonije 1942-1944. godine", u: Zbornik. Historijski institut Slavonije i Baranje, 12, Slavonski Brod, 1975., str. 16; Valentin Oberkersch, India. Deutsches Leben in Ostsyrmien (1825-1944), [Vlastita naklada], Stuttgart, 1978., str. 320; SLOBodan D. MilošEvić, Izbeglice i preseljenici na teritoriji okupirane Jugoslavije 1941-1945. godine, Narodna knjiga i Institut za savremenu istoriju, Beograd, 1981., str. 188-193; F. Hoffmann, Das Schicksal der Bosniendeutschen in 100 Jahren von 1878 bis 1978, str. 59-62; Dušan D. SAMARDŽIJa, Bosanskodubičko područje u NOR-u i socijalističkoj revoluciji 1941-1945, Društveno-političke organizacije i Skupština opštine Bosanska Dubica, Bosanska Dubica, 1984., str. 95-97; DušAN LukaČ, Treći Rajh i zemlje jugoistočne Evrope, III, 1941-1945, Vojnoizdavački zavod, Beograd, 1987., str. 728; V. OBERKERsCh, "Die Umsiedlung der Bosniendeutschen", str. 65-67; V. Oberkersch, Die Deutschen in Syrmien, Slawonien, Kroatien und Bosnien. Geschichte einer deutschen Volksgruppe in Südosteuropa, str. 387-390; PetAR KaČAvenDA, Nemci u Jugoslaviji 1918-1945., Institut za savremenu istoriju, Beograd, 1991., str. 126-127; Leidensweg der Deutschen im kommunistischen Jugoslawien, Band I, Ortsberichte über die Verbrechen an den Deutschen durch das Tito-Regime in der Zeit von 1944-1948, str. 810-829 ili Weißbuch der Deutschen aus Jugoslawien. Ortsberichte 1944-1948, str. 810-829; Leidensweg der Deutschen im kommunistischen Jugoslawien, Band II, Erlebnisberichte über die Verbrechen an den Deutschen durch das Tito-Regime in der Zeit von 19441948, Donauschwäbische Kulturstiftung, München - Sindelfingen, 1993., str. 827-842 ili Weißbuch der Deutschen aus Jugoslawien. Erlebnisberichte 1944-1948, Universitas, München, 1993., str. 827-842; Miloš Hamović, Izbeglištvo u Bosni i Hercegovini 19411945., "Filip Višnjić", Beograd, 1994., str. 396-397; H. Sundhaussen, "Die Deutschen in Kroatien-Slavonien und Jugoslawien", str. 343; E. ReDžIć, Bosna i Hercegovina u Drugom svjetskom ratu, str. 54-55; Carl Bethke, "Von der 'Umsiedlung' zur 'Aussiedlung'. Zur destruktiven Dynamik 'ethnischer Flurbereigung' am Beispiel der Deutschen in Bosnien und Kroatien", u: Mariana Hausleitner (Hrsg.), Vom Faschismus zum Stalinismus. Deutsche und andere Minderheiten in Ostmittel- und Südosteuropa 1941-1953, Institut für deutsche Kultur und Geschichte Südosteuropas, München, 2008., str. 2732; L. Perenčević, "'Pravo na zavičaj' - Identitet bosanskih Nijemaca u poslijeratnoj Njemačkoj", str. 161-164; L. Perenčević, "'Fern vom Land der Ahnen' - Zur Identitätskonstruktion in bosniendeutschen Heimatbüchern", str. 54-58; MARICA KARAKAš OBRadov, "Migracije njemačkog stanovništva na hrvatskom području tijekom Drugoga svjetskog rata i poraća", u: Scrinia slavonica, sv. 12, Slavonski Brod, 2012., str. 271-293; Marica Karakaš Obradov, Novi mozaici nacija u "novim poredcima". Migracije stanovništva na hrvatskom području tijekom Drugoga svjetskog rata i poraća, Hrvatski institut za povijest, Zagreb, 2014., str. 288. I tamo navedeni izvori i literatura.

36 Politisches Archiv Auswärtigen Amt, Bonn, Akten bettrefend Kroatien, Telegramm, 23. September 1942 № 2697; E. RedžIć, Bosna i Hercegovina u Drugom svjetskom ratu, str. 54-55. 
1944. i većina do tada u Nezavisnoj Državi Hrvatskoj, i u Bosni i Hercegovini, preostalih Nijemaca izbjegla je i napustila zavičaj. Početkom 1943. na udaru partizanskih snaga našle su se brojne skupine Nijemaca u Slavoniji, te je uslijedilo preseljavanje pripadnika njemačke narodne skupine iz zapadne i središnje Slavonije i Bosne i Hercegovine u okolicu Osijeka i u Srijem. Prema planu trebalo je tijekom 1943. preseliti oko $5000 \mathrm{Ni}$ jemaca iz preostalih njemačkih naselja u Bosni. Istovremeno iseljavaju se 21./22. rujna 1944. i preostali bosanskohercegovački Nijemci iz Wind(t) horsta, Adolfstala i Trošelja u Osijek, odakle preko Mađarske odlaze u Njemački Reich. Preostali Nijemci iz
Brčkog i okolice iseljeni su u sklopu iseljavanja pripadnika njemačke narodne skupine okruga Sava - Dunav i okruga Istočni Srijem, u jesen 1944., te je tako završeno iseljavanje Nijemaca iz Bosne i Hercegovine. ${ }^{37}$

Potkraj 1944. i početkom 1945. Narodnooslobodilačka vojska i partizanski odred Jugoslavije/Jugoslavenske armije i novouspostavljena "narodna" vlast počinje sustavno progoniti preostale folksdojčere u Jugoslaviji. Tome je napose pridonijela odluka Predsjedništva Antifašističkoga vijeća narodnog oslobođenja Jugoslavije od 21. studenoga 1944., koja je pripadnike njemačke manjine proglasila kolektivnim krivcima. $^{38}$ "Odluka o prijelazu

37 Usp. Arhiv Bosne i Hercegovine, Sarajevo (dalje: ABiH), ZKRZ za Bosnu i Hercegovinu, Inv. broj 59, kut. 6; Dokumentation der Vertreibung der Deutschen aus Ost-Mitteleuropa, Band V, Das Schicksal der Deutschen in Jugoslawien, str. 85E-87E; Z. KRnić, "O iseljavanju pripadnika Njemačke narodne skupine (Volksdeutschera) iz NDH za vrijeme II svjetskog rata", str. 78, 80, 83; Z. Krnić - S. Ljubljanović - C. Tomljanović, "Neki podaci o organizaciji i radu Njemačke narodne skupine u NDH", str. 7074; A. Miletić, "Preseljenje i evakuacija Folksdojčera iz Srijema i Slavonije 1942-1944. godine", str. 17-18; Friedrich G. LAmers, 65 Jahre Kolonien in Bosnien in Jugoslawien. Nova Topola (Windthorst) 1879-1944. Alexandrovac (Rudolfstal) 1880-1944, [St. Paul, Minnesota], 1970.; Friedrich G. Lamers, Zwei deutsche Kolonien in Bosnien. Erinnerungen an meine Heimat Windthorst, [St. Paul, Minnesota], 1978.; D. Lukač, Treći Rajh i zemlje jugoistočne Evrope, III, 1941-1945, str. 729-730; V. Овеrкersch, Die Deutschen in Syrmien, Slawonien, Kroatien und Bosnien. Geschichte einer deutschen Volksgruppe in Südosteuropa, str. 392, 425-427; P. KaČAVEnda, Nemci u Jugoslaviji 1918-1945., str. 132; Anton Scherer, "Die Flucht der Windhorster 1944. Das Walten der göttlichen Vorsehung war oft handgreiflich", u: Donauschwaben Kalender 1992, Aalen, 1991., str. 49-54; Alfred Benken - Heinz Benken, "Siedler aus Südoldenburg in Bosnien flohen vor Partisanen und der Sowjetarmee", u: Volkstum und Landschaft, Sonderbeilage (Heimatblätter) der Münsterländischen Tageszeitung, Nr. 275, Cloppenburg, 24. November 1995.; H. Sundhaussen, "Die Deutschen in Kroatien-Slavonien und Jugoslawien", str. 343; Vladimir Geiger, "Iseljavanje Njemačke narodne skupine u Nezavisnoj Državi Hrvatskoj s područja Slavonije potkraj Drugoga svjetskog rata", u: MARINA LuKšıč Hacin (ur.), Sezonstvo in izseljenstvo v panonskem prostoru: sosedstvo Avstrije, Hrvaške, Madžarske in Slovenije / Seasonal Work and Emigration in the Panonian Space: the Neighbourhood of Austria, Croatia, Hungary and Slovenia. Zbornik, 1, Znanstvenoraziskovalni center Slovenske akademije znanosti in umetnosti, Ljubljana, 2003., str. 161-174; Peter Schindler, 65 Jahre deutsche Kolonisten in Bosnien. Zwei geschlossene Kolonien Windthorst und Rudolfstal. Politische-Gemeinden [Nova Topola und Aleksandrovac] 18791944, [Hamburg], 2007. I tamo navedeni izvori i literatura.

38 Usp. Službeni list Demokratske Federativne Jugoslavije, god. I., br. 2, Beograd, 6. 2. 1945. , str. 13-14. 
u državno vlasništvo neprijateljske imovine, o državnoj upravi nad imovinom neprisutnih osoba i o sekvestru nad imovinom koju su okupatorske vlasti prisilno otuđile", Predsjedništva AVNOJ-a od 21. studenoga 1944., kojom se određuje i položaj jugoslavenskih Nijemaca, objavljena je sredinom prosinca 1944. i u Oslobodenju. ${ }^{39}$

Odluka Predsjedništva AVNOJ-a od 21. studenoga 1944. nije obvezivala dokazivanje potpomaganja okupatora, nego je pod udar došla svaka osoba njemačke narodnosti koja se nije izravno suprotstavila nacizmu. Žrtve kolektivne odmazde nisu bili samo oni jugoslavenski Nijemci koji su mogli dokazati svoje sudjelovanje u partizanskom pokretu ili njegovo pomaganje. Ostalima je slijedila konfiskacija imovine, upućivanje u logore i protjerivanje. Kako je i u nedvojbenim slučajevima dolazilo do nepravilnosti u provođenju Odluke Predsjedništva AVNOJ-a od 21. studenoga 1944., Predsjedništvo Ministarskog savjeta DF Jugoslavije zauzelo je izričito stajalište i 7. lipnja 1945. izvijestilo Državnu komisiju za repatrijaciju
Ministarstva socijalne politike DF Jugoslavije da je potrebno od kolektivne odgovornosti izdvojiti pripadnike njemačke manjine antifašiste. ${ }^{40}$

$\mathrm{Na}$ temelju Odluke Predsjednišstva AVNOJ-a od 21. studenoga 1944. doneseno je nekoliko odluka, uredbi, tumačenja i zakona, kojima je omogućen i na kraju ostvaren zakonit progon folksdojčera. Pitanje folksdojčera u Jugoslaviji riješeno je jednostrano i bez kompromisa. Odnos Narodnooslobodilačke vojske i partizanskih odreda Jugoslavije/Jugoslavenske armije i "narodnih" vlasti prema jugoslavenskim, i bosanskohercegovačkim Nijemcima, kojima je pripisana i ozakonjena kolektivna krivnja, ogledni je primjer etničkoga čišćenja u Jugoslaviji i Bosni i Hercegovini, potkraj Drugoga svjetskog rata i u poraću. ${ }^{41}$

Nakon preuzimanja vlasti u pojedinim naseljima, prema uputama Odjeljenja za zaštitu naroda za Bosnu i Hercegovinu, jedinice Korpusa narodne obrane Jugoslavije uhićivale su folksdojčere i odvodile ih u logore, odakle su trebali biti protjerani iz Jugoslavije. I

39 Usp. "Prelaz u državnu svojinu neprijateljske imovine", u: Oslobođenje, br. 19, 16. 12. 1944., str. 2.

40 Arhiv Jugoslavije, Beograd (dalje: AJ), Vlada Federativne Narodne Republike Jugoslavije - Predsedništvo, 35-73; Vladimir GeIGer, "Represija nad pripadniki nemške manjšine na Hrvaškem, v Bosni in Hercegovini ter Vojvodini, 1944-1948", u: Prispevki za novejšo zgodovino, št. 1, Ljubljana, 2013., str. 126.

41 Zoran Janjetović, Between Hitler and Tito. The disappearance of the Vojvodina Germans, [Vlastita naklada], Beograd, 2000., [Vlastita naklada], Beograd, 2005.; VLAdImir Geiger, "Folksdojčeri u Hrvatskoj 1945.", u: Nada Kisić Kolanović - Mario JAReb - Katarina SpehnjaK (ur.), 1945. - razdjelnica hrvatske povijesti. Zbornik, Hrvatski institut za povijest, Zagreb, 2006., str. 271-287; Vladimir Geiger, "Josip Broz Tito i sudbina jugoslavenskih Nijemaca", u: Časopis za suvremenu povijest, 3/2008., Zagreb, str. 801-818; Vladimir Geiger, Josip Broz Tito i ratni zločini. Bleiburg i folksdojčeri, Hrvatski institut za povijest, Zagreb, 2013., str. 31-50; V. Geiger, "Represija nad pripadniki nemške manjšine na Hrvaškem, v Bosni in Hercegovini ter Vojvodini, 1944-1948", str. 125-126, 136. I tamo navedeni izvori i literatura. 
malobrojne preostale bosanskohercegovačke Nijemce jugoslavenske komunističke vlasti protjerivale su i internirale u logore, kojih je bilo i u Bosni i Hercegovini (Bosanska Gradiška, Nova Topola kod Bosanske Gradiške, (Bosanski) Aleksandrovac kod Bosanske Gradiške, Lauš kod Banje Luke, Bosanska Dubica, Sarajevo, Zenica). ${ }^{42}$

Bosanskohercegovački Nijemci su u poraću bili internirani i u logore za folksdojčere u Hrvatskoj, ponajprije u logore u Slavoniji i Baranji (Josi- povac kod Osijeka, Valpovo, Velika Pisanica kod Bjelovara, Krndija kod Đakova, Šipovac kod Našica, Pusta Podunavlje u Baranji i Tenja/Tenjska Mitnica kod Osijeka), zatim i u logore u Bačkoj (Gakovo) i Banatu (Knićanin/Rudolfsgnad). ${ }^{43}$

Nijemci bosanske Posavine (Brčko, Bijeljina, Gradačac i Bosanski Šamac) u neposrednom su poraću 1945. uhićeni i internirani najprije u logor Josipovac kod Osijeka i logor Valpovo, odakle su trebali biti prognani u

42 Usp. ABiH, ZKRZ za Bosnu i Hercegovinu, Inv. broj 59, kut. 6; Deutsches Rotes Kreuz. Suchdienst. Zivilverschollenenliste. Skizzenblätter mit Angabe der Festnahmeorte und Gewahrsame sowie mit geographischer Darstellung der Lager nach Heimatkreisen alphabetisch geordnet. II Jugoslawien Sk - Kl/Lgl, Hamburg, 1962./1963.; Deutsches Rotes Kreuz. Suchdienst. Zivilverschollenenliste. Namenverzeichnis von in fremden Gewahrsam geratenen und verschollenen Zivilpersonen nach Heimatkreisen alphabetisch geordnet. C Jugoslawien $N$-Kl, Hamburg, 1962./1963.; Deutsches Rotes Kreuz. Suchdienst. Zivilverschollenenliste. Namenverzeichnis von in fremden Gewahrsam geratenen und verschollenen Zivilpersonen nach Lagerbereichen alphabetisch geordnet. D Jugoslawien N-Lgl, Hamburg, 1962./1963.; Leidensweg der Deutschen im kommunistischen Jugoslawien, Band I, Ortsberichte über die Verbrechen an den Deutschen durch das Tito-Regime in der Zeit von 1944-1948, str. 814 ili Weißbuch der Deutschen aus Jugoslawien. Ortsberichte 1944-1948, str. 814; Leidensweg der Deutschen im kommunistischen Jugoslawien, Band II, Erlebnisberichte über die Verbrechen an den Deutschen durch das Tito-Regime in der Zeit von 1944-1948, str. 828 ili Weißbuch der Deutschen aus Jugoslawien. Erlebnisberichte 1944-1948, str. 828; Husnija KAMBerović, Prema modernom društvu. Bosna i Hercegovina od 1945. do 1953. godine, Centar za kulturu i obrazovanje, Tešanj, 2000., str. 56-61; Skupina Autora, Ženski biografski leksikon - Sjećanje žena na život u socijalizmu, Centar za ženske studije, Zagreb, 2004., str. 191-194. ["Evelina Pantner"]; Toмo Vukšić, "Međucrkveno i međunacionalno pitanje u djelu i misli biskupa Alfreda Pichlera (I.)", u: Crkva u svijetu, Split, 1/2004., str. 135-139. ["Župnik Pichler i logorski čuvar Milan"]; Salih Jalimam - Slavko Marić - Rafet Spahić, Kazniona - knjiga o zeničkom zatvoru, Vrijeme, Zenica - NAM, Tuzla, 2008., str. 67 ili Salih Jalimam - Slavko Marić - Rafet Spahić, Kazniona - knjiga o zeničkom zatvoru / The Penitentiary. A Book about the Zenica Prison, Vrijeme, Zenica NAM, Tuzla, 2011., str. 23/24; Z. SulejMANPAšić, Više nas nisu hapsili 1931.-1950., str. 230-238. I tamo navedeni izvori i literatura.

43 Usp. Verbrechen an den Deutschen in Jugoslawien 1944-1948, str. 153-159, 180-198, 219228; Genocide of the Ethnic Germans in Yugoslavia 1944-1948, Donauschwäbische Kulturstiftung, München, 2003., str. 106-110, 113-116, 121-127; Genocid nad nemačkom manjinom u Jugoslaviji 1944-1948, Društvo za srpsko-nemačku saradnju (Beograd) i Donauschwäbische Kulturstiftung (München), Beograd - München, 2004., str. 134139, 142-146, 152-160; Z. Janjetović, Between Hitler and Tito. The disappearance of the Vojvodina Germans, Beograd, 2000., str. 256-294; Beograd, 2005., str. 249-286; Vladimir Geiger, "Logori za folksdojčere u Hrvatskoj nakon Drugoga svjetskog rata 1945.-1947.", u: Časopis za suvremenu povijest, 3/2006., Zagreb, str. 1081-1100. I tamo navedeni izvori i literatura. 
Austriju. ${ }^{44}$ U svibnju 1945. u Josipovcu kod Osijeka i Valpovu osnovani su prvi veliki sabirni centri/logori za hrvatske, posebice slavonske, srijemske, baranjske, ali i bosansko-posavske Nijemce. Prve skupine folksdojčera, internirane su najprije u Josipovcu. Tijekom svibnja 1945. u logor Josipovac internirano je više od 3000 osoba, uglavnom starijih osoba, žena i djece. Transporti s folksdojčerima iz logora Josipovac i logora Valpovo, a i drugih logora, upućivani su od početka srpnja 1945. u Austriju. U prepunim stočnim vagonima, bez dovoljno hrane i vode, većina iscrpljena pobolijeva, a neki višednevno putovanje nisu preživjeli. Iz logora Josipovac 8 . srpnja 1945. upućen je željeznički transport s oko 3000 logoraša. Nakon iscrpljujućega puta logoraši su dva dana bili zatvoreni u stočnim vagonima u Leibnitzu u Austriji, a zatim ih je oružana pratnja istjerala i ostavila. Logor Jo- sipovac je raspušten 10. srpnja 1945. a manji broj logoraša koji je preostao prebačen je u logor Valpovo. Zatim je stočnim vagonima 22. srpnja 1945 . iz logora Valpovo prema Austriji upućeno još 1800 osoba. Međutim, kako su britanske okupacijske vlasti u Austriji odbile prihvatiti ih, transport se morao vratiti s granice, a nakon nekoliko dana besciljnoga kretanja, završio je u Velikoj Pisanici kod Bjelovara. Isto se tijekom srpnja 1945. dogodilo i s još dva transporta. Nakon kraćega zadržavanja folksdojčera u Velikoj Pisanici, od početka, a zaključno s 10 . kolovoza 1945., krenuli su transporti prema logorima za folksdojčere na istoku Hrvatske, logor Šipovac kod Našica, logor Krndija kod Đakova i logor Valpovo. To je značilo i nastavak stradanja slavonskih, srijemskih, baranjskih i bosansko-posavskih $\mathrm{Ni}$ jemaca koji su bili u tim transportima. ${ }^{45}$ Nakon ukidanja logora za folk-

44 Usp. Dokumentation der Vertreibung der Deutschen aus Ost-Mitteleuropa, Band V, Das Schicksal der Deutschen in Jugoslawien, str. 521-524; Leidensweg der Deutschen im kommunistischen Jugoslawien, Band II, Erlebnisberichte über die Verbrechen an den Deutschen durch das Tito-Regime in der Zeit von 1944-1948, str. 828-829 ili Weißbuch der Deutschen aus Jugoslawien. Erlebnisberichte 1944-1948, str. 828-829. I tamo navedeni izvori i literatura.

45 Usp. Leopold Rohrbacher, Ein Volk ausgelöscht. Die Ausrottung des Donauschwabentums in Jugoslawien in den Jahren von 1944 bis 1948, Forschungsinstitut für Fragen der Heimatlosen, Salzburg, 1949., str. 198-200 ili Völkermord der Tito-Partisanen 19441948. Der Vernichtung der altösterreichischen Deutschen Volksgruppe in Jugoslawien und die Massaker an Kroaten und Slowenen. Dokumentation, Österreichische Historiker Arbeitsgemeinschaft für Kärnten und Steiermark, Graz, 1991., str. 191-193; Dokumentation der Vertreibung der Deutschen aus Ost-Mitteleuropa, Band V, Das Schicksal der Deutschen in Jugoslawien, str. 521-538; Leidensweg der Deutschen im kommunistischen Jugoslawien, Band II, Erlebnisberichte über die Verbrechen an den Deutschen durch das Tito Regime in der Zeit von 1944-1948, str. 768-769, 775-776, 799, 825-826, 829 ili Weißbuch der Deutschen aus Jugoslawien. Erlebnisberichte 1944-1948, str. 768-769, 775-776, 799, 825-826, 829; Leidensweg der Deutschen im kommunistischen Jugoslawien, Band III, Erschießungen-Vernichtungslager-Kinderschicksale in der Zeit von 1944 bis 1948, str. 885-887 ili Weißbuch der Deutschen aus Jugoslawien. Erschießungen - Vernichtungslager Kinderschicksale in der Zeit von 1944-1948, str. 885-887; Verbrechen an den Deutschen in Jugoslawien 1944-1948. Die Station eines Völkermords, str. 219-221; Genocide of the Ethnic Germans in Yugoslavia 1944-1948, str. 121-122; Genocid nad nemačkom manjinom u Jugoslaviji 1944-1948, str. 152-154; V. GEIGER, "Folksdojčeri u Hrvatskoj 1945.", str. 
sdojčere u Hrvatskoj 1946./1947. i u Bosni i Hercegovini 1945./1946. preostali logoraši prebačeni su u logore u Vojvodini, koji su postojali do početka 1948., a koje mnogi zbog bolesti i gladi nisu preživjeli. ${ }^{46}$

Dugotrajnost i intenzitet Drugoga svjetskog rata na području Nezavisne Države Hrvatske, posebno na području Bosne i Hercegovine, i prisutnost znatnih okupacijskih snaga Njemačkoga Reicha i Italije te djelovanje Oružanih snaga NDH, četnika - Jugoslovenske vojske u Otadžbini i partizana - Narodnooslobodilačke vojske i partizanskih odreda Jugoslavije/Jugoslavenske armije imalo je za posljedicu izravne sukobe zaraćenih strana, što je dovelo i do velikih ljudskih gubitaka i među vojnicima i među stanovništvom. Nepomirljive ideologije i politički i vojni interesi suprotstavljenih strana u ratnom sukobu i građanskom ratu umnožili su ljudske gubitke.

Ratni zločini koje je dio jugoslavenskih, pa i bosanskohercegovačkih Nijemaca počinio, te njihovo nelojalno držanje tijekom Drugoga svjetskog rata i okupacije, poslužili su i kao razlog i kao opravdanje za neljudsko postupanje s njemačkom manjinom potkraj rata i u poraću. No, kolaboracija jugoslavenskih folksdojčera ne razlikuje se u mnogočemu od primjerice mađarske, albanske, talijanske ili bugarske. Nakon svega kolektivnim krivcima proglašeni su samo Nijemci. ${ }^{47}$ Nova je jugoslavenska vlast, kao i za druge "neprijatelje naroda" i "ratne

271-287; V. GEIger, "Logori za folksdojčere u Hrvatskoj nakon Drugoga svjetskog rata 1945.-1947.", str. 1081-1100; Vladimir Geiger (prir.), Radni logor Valpovo 1945.-1946. Dokumenti, Njemačka narodnosna zajednica Zemaljska udruga Podunavskih Švaba u Hrvatskoj/Volksdeutsche Gemeinschaft Landsmannschaft der Donauschwaben in Kroatien, Osijek, 1999.; Vladimir Geiger, "Logor Velika Pisanica 1945. godine", u: Godišnjak Njemačke narodnosne zajednice/VDG Jahrbuch 1999, Osijek, 1999., str. 151160; Vladimir Geiger, "Sabirni i prolazni logor za folksdojčere u Velikoj Pisanici kod Bjelovara 1945.", u: Tokovi istorije, br. 1, Beograd, 2011., str. 76-90; Vladimir Geiger, "Radni logor Šipovac-Našice 1945. godine", u: Godišnjak Njemačke narodnosne zajednice/VDG Jahrbuch 2001, Osijek, 2001., str. 239-250; Vladimir Geiger - Branko KranjČev, "Radni logor Šipovac 1945./46. godine", u: Našički zbornik, br. 7, Našice, 2002., str. 125-142; Vladimir Geiger, Logor Krndija 1945.-1946., Hrvatski institut za povijest (Zagreb) - Hrvatski institut za povijest, Podružnica za povijest Slavonije, Srijema i Baranje, Zagreb - Slavonski Brod, 2008.; C. Bethke, "Von der 'Umsiedlung' zur 'Aussiedlung'. Zur destruktiven Dynamik 'ethnischer Flurbereigung' am Beispiel der Deutschen in Bosnien und Kroatien", str. 35-36; Vladimir Geiger, "'Bezimeni' - vlč. Josip Konopka, kapelan iz Bijeljine, u logoru Krndija kod Đakova, 1945.-1946.", u: Politički zatvorenik, br. 252, Zagreb, svibanj/lipanj 2013., str. 30-31. I tamo navedeni izvori i literatura.

46 Verbrechen an den Deutschen in Jugoslawien 1944-1948, str. 227-228; Genocide of the Ethnic Germans in Yugoslavia 1944-1948, str. 126; Genocid nad nemačkom manjinom u Jugoslaviji 1944-1948, str. 159-160; Z. Janjetović, Between Hitler and Tito. The disappearance of the Vojvodina Germans, Beograd, 2000., str. 256-294; Beograd, 2005., str. 249-286; V. Geiger, "Logori za folksdojčere u Hrvatskoj nakon Drugoga svjetskog rata 1945.-1947.", str. 1095-1096, 1099; V. GEIGER, "Represija nad pripadniki nemške manjšine na Hrvaškem, v Bosni in Hercegovini ter Vojvodini, 1944-1948", str. 133.

47 Zoran Janjetović, "Logorisanje vojvođanskih Nemaca od novembra 1944. do juna 1945. godine", u: Tokovi istorije, br. 1-2, Beograd, 1997., str. 163; V. Geiger, "Josip Broz 
zločince", nastojala prikupiti podatke i potkrijepiti takvo svoje stajalište i odnos prema folksdojčerima. ${ }^{48}$ Bilo je to vrijeme kada je svaki Nijemac građanin Jugoslavije bio sumnjiv i ratni zločinac, ako se drukčije ne dokaže. Političko ozračje kojemu su pridonijela takva stajališta i postupci, bilo je sve prije nego li normalno stanje.

No, u sagledavanju i razumijevanju povijesti bosanskohercegovačkih $\mathrm{Ni}$ jemaca nije zanemariva činjenica da je pet bosanskohercegovačkih Nijemaca i Njemica (Josip i Rozika Eberhardt i Adam Till iz Sarajeva i Franjo i Lidija Griner iz Mostara) zbog iskazane ljudskosti i zaštite bosanskohercegovačkih Židova tijekom Drugoga svjetskog rata proglašeno Pravednicima medu narodima. ${ }^{49}$
Jugoslavenske su vlasti zauzele stajalište o zabrani povratka tijekom rata izbjeglih i prognanih folksdojčera iz Jugoslavije. Odluka da se onemogući povratak jugoslavenskih folksdojčera donesena je na sjednici Državne komisije za repatrijaciju, Beograd 22. svibnja 1945., s čime su se, zatim, suglasili Vlada Demokratske Federativne Jugoslavije i Generalštab Jugoslavenske armije. Štoviše, vlasti su i preostale folksdojčere u Jugoslaviji namjeravale protjerati iz zemlje. Predsjedništvo Ministarskoga savjeta DF Jugoslavije, Beograd, izvijestilo je 11. lipnja 1945.: "Vlada Jugoslavije stoji na stanovištu da sve Njemce koji se nalaze u okviru granica Jugoslavije raseli i uputi u Njemačku, čim se zato stvore povoljni tehnički uslovi."50

Tito i sudbina jugoslavenskih Nijemaca", str. 802; V. GeIger, Josip Broz Tito i ratni zločini. Bleiburg i folksdojčeri, str. 32; V. GeIger, "Represija nad pripadniki nemške manjšine na Hrvaškem, v Bosni in Hercegovini ter Vojvodini, 1944-1948", str. 123.

48 Usp. ABiH, ZKRZ za Bosnu i Hercegovinu, Inv. broj 59, kut. 6; Pretsjedništvo ZAVNOBIH-a Zemaljska komisija za utvrđivanje zločina okupatora i njihovih pomagača, Upute za rad Opštinskih komisija za utvrdivanje zločina okupatora i njihovih pomagača, Tuzla, 1945.

49 Usp. Eli TAuber, Kada su komšije bili ljudi, Institut za istraživanje zločina protiv čovječnosti i međunarodnog prava Univerziteta, Sarajevo, 2008. ili Eli TAuBER, When neighbors were real human beings, Institut za istraživanje zločina protiv čovječnosti i međunarodnog prava Univerziteta, Sarajevo, 2010.

50 AJ, Vlada Federativne Narodne Republike Jugoslavije - Predsedništvo, 35-73; HDA, OF Rittig Svetozar, kut. 1, fasc. 5 "Protjerivanje Nijemaca iz FNRJ" - Zemaljska komisija za repatriaciju Njemaca pri Ministarstvu unutrašnjih poslova Federativne države Hrvatske, Broj 1/45., Predmet: Njemaca naših državljana repatriacija (iselenje Njemaca) -upute-, Zagreb, 7. VII. 1945.; H. Kamberović, Prema modernom društvu. Bosna i Hercegovina od 1945. do 1953. godine, str. 56; Vladimir Geiger, "Folksdojčeri - Fatum kolektivne krivnje", u: Godišnjak Njemačke narodnosne zajednice/VDG Jahrbuch 2002, Osijek, 2002., str. 294; Vladimir Geiger, "Heimkehr. Povratak slavonskih Nijemaca nakon Drugoga svjetskog rata iz izbjeglištva/prognaništva u zavičaj i njihova sudbina", u: Scrinia slavonica, sv. 3, Slavonski Brod, 2003., str. 521-522, 525; ZDRAvko DizDAR - VLADimir Geiger - Milan PojIĆ - Mate Rupić (prir.), Partizanska i komunistička represija i zločini u Hrvatskoj 1944.-1946. Dokumenti, Hrvatski institut za povijest - Podružnica za povijest Slavonije, Srijema i Baranje, Slavonski Brod, 2005., Zagreb, 2009., str. 179-182; Vladimir GeIger (prir.), Partizanska i komunistička represija i zločini u Hrvatskoj 1944.1946. Dokumenti. Slavonija, Srijem i Baranja, Hrvatski institut za povijest - Podružnica za povijest Slavonije, Srijema i Baranje, Slavonski Brod, 2006., str. 245-248; VLAdimir Geiger (prep.), Partisan and Communist Repression and Crimes in Croatia 1944-1946. Documents. Slavonia, Syrmia and Baranya, University of Mary Press, Bismarck, North 
Ministarstvo za Bosnu i Hercegovinu DF Jugoslavije, Beograd, uputilo je 14. lipnja 1945. Predsjedništvu Narodne Vlade Bosne i Hercegovine, Sarajevo, dopis kojim naglašava: "Posle sloma Nemačke pojavili su se na našoj granici prema Austriji neki Nemci, koji su za vreme okupacije iseljeni s teritorije Bosne. Oni pokušavaju da udju u našu zemlju. Iako je našim graničnim vlastima dato naredjenje da ih ne puštaju u zemlju, ima obaveštenja da se izvestan broj tih Nemaca prebacio na neki način preko granice..." 51

Nijemci, koji su se vratili u zavičaj, tražili su natrag svoja imanja, kao primjerice u kotaru Prnjavor. Pri tome "narodne vlasti još nemaju uputstva kakav stav da zauzmu prema njima". Predsjedništvo Narodne Vlade Bosne i Hercegovine zamoljeno je "da preduzme mere radi ispitivanja: na koji način su se ti Nemci prebacili preko granice, da bi se odmah sprečilo ponavljanje takvih slučajeva". Ministarstvo za Bosnu i Hercegovinu naglašava u dopisu Predsjedništvu Narodne Vlade Bosne i Hercegovine 14. lipnja 1945., da je već ranije Ministarski savjet Jugoslavije izdao jedan povjerljiv raspis po kojemu Nijemce, koji su se uspjeli vratiti, ne treba puštati na njihova imanja, nego ih treba internirati u logore ("Ne puštati Nemce na njihova imanja, držati ih u logoru internirane $\mathrm{i}$ upotrebljavati ih za radove..."). ${ }^{52}$ Upravni odjel Narodnog odbora Bosanska Gradiška izvijestio je 21. kolovoza 1945., Okružni narodni odbor Banja Luka, da je postupio po naređenju, koje je Upravno odjeljenje Okružnog narodnog odbora Bosanska Gradiška proslijedilo 10. lipnja 1945. potčinjenim organima vlasti o protjerivanju Nijemaca, ustaša i četnika u radne logore: "...svi Njemci koji su ostali kod svojih kuća, kao i oni koji su pristizali iz raznih krajeva s namjerom da se povrate svojim kućama, upućeni su u radne logore, kao i ovi koji još pristižu." 53

$\mathrm{Na}$ Potsdamskoj konferenciji (17. srpnja do 2. kolovoza 1945.) savezničkih velesila pobjednica u ratu, zaključeno je (XIII "Uredno iseljavanje njemačkog stanovnišstva") da se preostalo njemačko stanovništvo iz Poljske, Cehoslovačke i Mađarske mora preseliti na područje Njemačke. Preseljenje (etničko čišćenje) legalizirano je kao najtrajnije i zadovoljavajuće rješenje i trebalo se obaviti "organizirano i na human način". ${ }^{44}$ Države koje se nisu našle u zaključcima Potsdamske

Dakota, 2011., str. 212-217; V. Geiger, "Josip Broz Tito i sudbina jugoslavenskih Nijemaca", str. 803; V. Geiger, Josip Broz Tito i ratni zločini. Bleiburg i folksdojčeri, str. 34; V. Geiger, "Represija nad pripadniki nemške manjšine na Hrvaškem, v Bosni in Hercegovini ter Vojvodini, 1944-1948", str. 126.

51 AJ, Ministarstvo federalnih jedinica DF Jugoslavije, 1-132; H. Kamberović, Prema modernom društvu. Bosna i Hercegovina od 1945. do 1953. godine, str. 57.

52 Isto.

53 Arhiv Republike Srpske, Banja Luka (dalje: ARS), Okružni narodni odbor Banja Luka, kut. 125, dok. br. Pov. 166/45.; H. Kamberović, Prema modernom društvu. Bosna i Hercegovina od 1945. do 1953. godine, str. 56.

54 Ujedinjene nacije. Zbirka dokumenata 1941-1945, Arhiv za pravne i društvene nauke, Beograd, 1947., str. 124-125; The Tehran, Yalta \& Potsdam Conferences. Documents, Progress Publishers, Moscow, 1969., str. 332-333. 
konferencije, riješile su problem folksdojčera na još drastičniji način, ponajprije Jugoslavija.

Pitanje tzv. raseljenih osoba (Displaced Persons), posebice folksdojčera kojih je krajem Drugoga svjetskog rata i u poraću bilo najviše, bilo je za Austriju veliki gospodarski, socijalni i politički problem. Od sredine 1945. problem raseljenih osoba u Austriji počeo se izrazito zaoštravati. Čehoslovačka, Mađarska i Jugoslavija otpočele su tada masovno protjerivati folksdojčere. Austrijska vlada prosvjedovala je saveznicima i inzistirala da se neodgodivo zatvore austrijske gra- nice. ${ }^{55}$ Britanske, američke i sovjetske okupacijske vlasti u Austriji, ne samo da su poticale povratak folksdojčera u Jugoslaviju, nego su iskazivale i protivljenje jugoslavenskim nastojanjima da onemoguće povratak izbjeglical prognanika, a napose su se protivile jugoslavenskim nastojanjima da folksdojčere protjeruju iz Jugoslavije. ${ }^{56}$ Kako je protjerivanje folksdojčera iz Jugoslavije zbog zatvaranja granice prema Austriji, Italiji i Mađarskoj od savezničkih okupacijskih vlasti sredinom srpnja 1945. to onemogućilo, za većinu jugoslavenskih Nijemaca slijede logori i prisilni rad..$^{7}$

55 DušAn NeĆAK, "O problemu 'razseljenih oseb' (D. Ps.) in jugoslovanskih 'Volksdeutscherjev' v Austriji te o britanski ideji njihove zamenjave s koroškimi Slovenci $(1945$ - 1947)", u: Zgodovinski časopis, št. 4 (105), Ljubljana, 1996., str. 561-571; Zoran JaNJETović, "Odlazak vojvođanskih Švaba - proterivanje ili iseljavanje", u: Tokovi istorije, br. 3-4, Beograd, 1997., str. 113; V. GeIger, "Folksdojčeri - Fatum kolektivne krivnje", str. 294-295; V. Geiger, "Logori za folksdojčere u Hrvatskoj nakon Drugoga svjetskog rata 1945.-1947.", str. 1084; V. GEIGER, "Represija nad pripadniki nemške manjšine na Hrvaškem, v Bosni in Hercegovini ter Vojvodini, 1944-1948", str. 128-129.

56 V. Geiger, "Heimkehr. Povratak slavonskih Nijemaca nakon Drugoga svjetskog rata iz izbjeglištva/prognaništva u zavičaj i njihova sudbina", str. 521-524, 527; V. GEIGER, "Represija nad pripadniki nemške manjšine na Hrvaškem, v Bosni in Hercegovini ter Vojvodini, 1944-1948", str. 129. I tamo navedeni izvori i literatura.

57 Dokumentation der Vertreibung der Deutschen aus Ost-Mitteleuropa, Band V, Das Schicksal der Deutschen in Jugoslawien, Düsseldorf, 1961., München, 1984., Augsburg, 1994. München, 2004., str. 100E-101E; Leidensweg der Deutschen im kommunistischen Jugoslawien, Band I, Ortsberichte über die Verbrechen an den Deutschen durch das Tito-Regime in der Zeit von 1944-1948, str. 662, 722, 726, 728, 732-734, 744, 748-749, 779, 787, 791 ili Weißbuch der Deutschen aus Jugoslawien. Ortsberichte 1944-1948, str. 662, 722, 726, 728, 732-734, 744, 748-749, 779, 787, 791; Leidensweg der Deutschen im kommunistischen Jugoslawien, Band II, Erlebnisberichte über die Verbrechen an den Deutschen durch das Tito-Regime in der Zeit von 1944-1948, str. 796-800, 812-814, 819-824 ili Weißbuch der Deutschen aus Jugoslawien. Erlebnisberichte 1944-1948, str. 796-800, 812-814, 819-824; Leidensweg der Deutschen im kommunistischen Jugoslawien, Band III, Erschießungen-Vernichtungslager-Kinderschicksale in der Zeit von 1944 bis 1948, str. 885, 887 ili Weißbuch der Deutschen aus Jugoslawien. Erschießungen - Vernichtungslager - Kinderschicksale in der Zeit von 1944-1948, str. 885, 887; V. Oberkersch, Die Deutschen in Syrmien, Slawonien, Kroatien und Bosnien. Geschichte einer deutschen Volksgruppe in Südosteuropa, str. 465; D. NeĆAK, "O problemu 'razseljenih oseb' (D. Ps.) in jugoslovanskih 'Volksdeutscherjev' v Austriji te o britanski ideji njihove zamenjave $s$ koroškimi Slovenci (1945-1947)", str. 561-571; Z. JANJETović, "Odlazak vojvođanskih Švaba - proterivanje ili iseljavanje", str. 113; V. GeIGER, "Folksdojčeri u Hrvatskoj 1945.", str. 277-278; V. Geiger, "Logori za folksdojčere u Hrvatskoj nakon Drugoga svjetskog rata 1945.-1947.", str. 1084; V. GeIger, "Represija nad pripadniki nemške manjšine na Hrvaškem, v Bosni in Hercegovini ter Vojvodini, 1944-1948", str. 130. I tamo navedeni izvori i literatura. 
Pitanje njemačke imovine u Jugoslaviji riješeno je bez kompromisa. $\mathrm{Na}$ ime, nije postavljena razlika između njemačke državne i privatne imovine, jer su Nijemci, jugoslavenski državljani, izjednačeni potpuno $s$ Nijemcima iz Njemačkoga Reicha i proglašeni su neprijateljima jugoslavenskih naroda. Tijekom priprema za agrarnu reformu i kolonizaciju postavilo se pitanje odnosi li se Odluka Predsjedništva AVNOJ-a od 21. studenoga 1944. i na imovinu Austrijanaca, austrijskih državljana i jugoslavenskih državljana koji su se tako iskazivali, te je Predsjedništvo Ministarskoga savjeta DF Jugoslavije 26. rujna 1945. zauzelo stajalište da Odluku AVNOJ-a od 21. studenoga 1944. treba primjenjivati i na imovinu Austrijanaca, s iznimkama koje su predviđene u Odluci Predsjednišstva AVNOJ-a, odnosno u naknadno izdanom tumačenju. ${ }^{58}$ U Jugoslaviji je sveukupno konfiscirano oko 100.000 njemačkih posjeda površine 637.939 hektara. U Bosni i
Hercegovini oduzeto je 3523 posjeda površine 12.733 hektara. Postupak konfiskacije je zahtijevao samo da se utvrdi da je određena imovina na dan stupanja na snagu Odluke Predsjedništva AVNOJ-a od 21. studenoga 1944. pripadala osobama njemačkoga državljanstva ili njemačke narodnosti. ${ }^{59}$ Najviše njemačkih posjeda u Bosni i Hercegovini konfiscirano je u banjalučkom okrugu, 3332 imanja (do kraja 1945. pravno "dovršeno" 2869). ${ }^{60}$

Procjenjuje se da je od oko 500.000 jugoslavenskih Nijemaca do potkraj Drugoga svjetskog rata znatan broj izbjegao, a da je, ne računajući pripadnike vojnih i poluvojnih postrojbi, oko 200.000 Nijemaca civila, potpalo pod komunističku vlast u Jugoslaviji. Od toga je jedna četvrtina nastradala u internacijskim logorima, od potkraj 1944. do početka 1948., dok je ostatak nestao tijekom etničkoga čišćenja potkraj Drugoga svjetskog rata i u neposrednom poraću. ${ }^{61}$

58 Nikola GaćEšA, Agrarna reforma i kolonizacija u Jugoslaviji 1945-1948, Matica srpska, Novi Sad, 1984., str. 218-219; Vladimir Geiger, "Položaj Austrijanaca u Hrvatskoj (i Jugoslaviji) 1945.-1965.", u: Nives Rittig-Beljak (ur.), Prvi i drugi medunarodni seminar Zajednice Nijemaca u Hrvatskoj 2001./2002. Zbornik radova, Zajednica Nijemaca u Hrvatskoj, Zagreb - Varaždin, 2001., str. 16-17; V. Geiger, "Represija nad pripadniki nemške manjšine na Hrvaškem, v Bosni in Hercegovini ter Vojvodini, 1944-1948", str. 128.

59 Usp. Hamdija ČEMERLIĆ (prir.), Zemaljsko antifašističko vijeće narodnog oslobođenja Bosne i Hercegovine. Dokumenti 1945., Knjiga II., Izdavačko preduzeće Veselin Masleša, Sarajevo, 1968., str. 286-288; Leopold EgGer, Das Vermögen und die Vermögenverluste der Deutschen in Jugoslawien, Landsmannschaft der Donauschwaben in BadenWürttemberg e.V., Sindelfingen, 1983.; N. GAĆEŠA, Agrarna reforma i kolonizacija u Jugoslaviji 1945-1948, str. 78-79, 362; V. GEIGER, "Folksdojčeri - Fatum kolektivne krivnje", str. 290-291; V. Geiger, "Represija nad pripadniki nemške manjšine na Hrvaškem, v Bosni in Hercegovini ter Vojvodini, 1944-1948", str. 128. I tamo navedeni izvori i literatura.

60 H. Kamberović, Prema modernom društvu. Bosna i Hercegovina od 1945. do 1953. godine, str. 60.

61 Dokumentation der Vertreibung der Deutschen aus Ost-Mitteleuropa, Band V, Das Schicksal der Deutschen in Jugoslawien, Düsseldorf, 1961., München, 1984., Augsburg, 1994., München, 2004.; Leidensweg der Deutschen im kommunistischen Jugoslawien, Band IV, 
U logore su upućivane cjelokupne njemačke obitelji, pretežito starije osobe, žene s djecom, bez obzira na dob. O strukturi jugoslavenskih Nijemaca logoraša najslikovitije je izvješće Ministarstva unutarnjih poslova FNR Jugoslavije, od 18. siječnja 1946. (Tabelarni pregled logorisanih i nelogorisanih Nemaca na teritoriji Jugoslavije), koje navodi da je na području Jugoslavije u logorima 117.485 folksdojčera, od toga 34.214 muškaraca, 58.821 žena i 24.422 djece (zbroj interniranih folksdojčera muškaraca, žena i djece nešto je manji od ukupnoga broja interniranih folksdojčera, koji je iskazan), a da se na slobodi nalazi 12.897 folksdojčera. Prema izvješću, na području Bosne i Hercegovine u logorima je 1117 folksdojčera, od toga 469 muškaraca, 222 žene i 426 djece, a na slobodi se nalaze 4 osobe njemačke narodnosti (1 muškarac, 1 žena i 2 djece). ${ }^{62}$ To ukazuje, da su preniske njemačke/ folksdojčerske procjene da je u poraću u jugoslavenske logore internirano 580, a da je na slobodi ostalo odnosno da nije internirano 70 bosanskohercegovačkih Nijemaca. ${ }^{63}$

Najveći broj bosanskohercegovačkih Nijemaca interniran je u logore u Bosni i Hercegovini i Hrvatskoj tijekom ljeta 1945. U najvećim i najdugotrajnijim logorima za Nijemce u Bosni i Hercegovini, Novoj Topoli i Bosanskom Aleksandrovcu kod Bosanske Gradiške, bilo je početkom kolovoza 1945. internirano 620 osoba "njemačkog porijekla" i članova Kulturbunda, među kojima i znatan broj "male djece i staraca

Menschenverluste - Namen und Zahlen zu Verbrechen an den Deutschen durch das Tito-Regime in der Zeit von 1944-1948, Donauschwäbische Kulturstiftung, München - Sindelfingen 1994.; Verbrechen an den Deutschen in Jugoslawien 1944-1948. Die Stationen eines Völkermords, str. 4, 290; Genocide of the Ethnic Germans in Yugoslavia 1944-1948, str. 155.; Genocid nad nemačkom manjinom u Jugoslaviji 1944-1948, str. 196. Usp. Zoran D. JAnjetović, "Izračunavanje broja žrtava Drugog svetskog rata u Jugoslaviji - jedno iskustvo", u: Dijalog povjesničara - istoričara, 5, Zagreb, 2002., str. 503-515; Vladimir Geiger, "Ljudski gubici Hrvatske u Drugome svjetskom ratu i u poraću koje su prouzročili Narodnooslobodilačka vojska i Partizanski odredi Jugoslavije/Jugoslavenska armija i komunistička vlast. Brojidbeni pokazatelji (procjene, izračuni, popisi). Case study: Bleiburg i folksdojčeri", u: Časopis za suvremenu povijest, 3/2010., Zagreb, str. 702-720; V. GeIger, Josip Broz Tito i ratni zločini. Bleiburg i folksdojčeri, str. 60-77.

62 AJ, Vlada Federativne Narodne Republike Jugoslavije - Predsedništvo, 35/844 - Tabelarni pregled logorisanih i nelogorisanih Nemaca na teritoriji Jugoslavije; Partizanska i komunistička represija i zločini u Hrvatskoj 1944.-1946. Dokumenti, str. 312; Michael PorTMann, "Politik der Vernichtung? Die deutschsprachige Bevölkerung in der Vojvodina 1944-1952. Ein Forschungsbericht auf Grundlage jugoslawischer Archivdokumente", u: Damubiana Carpathica, 1 (48), München, 2007., str. 357; Michael Portmann, Die kommunistische Revolution in der Vojvodina 1944-1952. Politik, Gesellschaft, Wirtschaft, Kultur, Verlag der Österreichischen Akademie der Wissenschaften, Wien, 2008., str. 255; V. GeIgER, "Represija nad pripadniki nemške manjšine na Hrvaškem, v Bosni in Hercegovini ter Vojvodini, 1944-1948", str. 132.

63 Usp. Leidensweg der Deutschen im kommunistischen Jugoslawien, Band III, ErschießungenVernichtungslager-Kinderschicksale in der Zeit von 1944 bis 1948, str. 941 ili Weißbuch der Deutschen aus Jugoslawien. Erschießungen - Vernichtungslager - Kinderschicksale in der Zeit von 1944-1948, str. 941; K. Weber, "Bevölkerung und Verluste. Die demographische Erfassung der Jugoslawiendeutschen", str. 72; Verbrechen an den Deutschen in Jugoslawien 1944-1948. Die Stationen eines Völkermords, str. 291. 
koji često obolijevaju". ${ }^{64}$ Unatoč učestaloj smrtnosti u logorima, broj interniranih folksdojčera se priljevom novih logoraša tijekom ljeta 1945. povećavao. Krajem kolovoza 1945. u logoru Nova Topola internirano je 709 osoba, 382 radno sposobnih i 327 radno nesposobnih, što najslikovitije prikazuje dobnu strukturu logoraša. ${ }^{65}$ Krajem studenoga 1945. u logorima u Novoj Topoli i Bosanskom Aleksandrovcu internirano je više od 1000 bosanskohercegovačkih Nijemaca, "ljudi, žena i djece. Prilike u tom logoru su prilično teške, naročito u pogledu smještaja. (...) Zdravstveni uslovi su loši". 66

$\mathrm{Na}$ tešku sudbinu interniranih folksdojčera utjecali su, osim nepovoljnih uvjeta smještaja, izrazito slaba prehrana, nemogućnost održavanja higijene, pomanjkanja lijekova i liječničke pomoći, razne zarazne bolesti, te naporan fizički rad po često nepovoljnim vremenskim prilikama. Stradavalo se većinom od bolesti, posebice dizenterije, tifusa pjegavca, ali i iscrpljenosti i gladi. Od samih početaka u logori- ma za folksdojčere u Jugoslaviji, javljaju se najprije zdravstvene poteškoće kod starijih i slabijih osoba i djece, a zatim dolazi i do pojave raznih zaraznih bolesti. Od jeseni/zime 1945., u logorima za folksdojčere haraju epidemije tifusa pjegavca i u zimu 1946. poprimaju zastrašujuće razmjere. Tek potkraj ožujka ili početkom travnja 1946., nakon poduzetih potrebnih mjera, tifus u logorima za folksdojčere u Jugoslaviji uglavnom je uklonjen. Kada su se zdravstvene i prehrambene prilike u logorima koliko-toliko normalizirale, život je i dalje bio jedva podnošljiv. ${ }^{67}$ To potvrđuju i zapisi te iskazi/svjedočanstva bosanskohercegovačkih Nijemaca interniraca u logoru Nova Topola, a i iskazi/svjedočanstva suvremenika. ${ }^{68}$

Iako su logori za folksdojčere u Jugoslaviji osnovani potkraj 1944. na području Vojvodine, a na području Hrvatske i Bosne i Hercegovine u svibnju 1945., tek je početkom svibnja 1946. Ministarstvo unutarnjih poslova FNR Jugoslavije donijelo "Uputstvo o organizaciji života i rada u logori-

64 ARS, Okružni narodni odbor Banja Luka, kut. 143, dok. br. 13170/45., 5. 8. 1945.; H. KAMBerović, Prema modernom društvu. Bosna i Hercegovina od 1945. do 1953. godine, str. 59.

65 ARS, Okružni narodni odbor Banja Luka, kut. 145, dok. br. 14497/45., 30. 8. 1945.; H. KAMBERović, Prema modernom drustuu. Bosna i Hercegovina od 1945. do 1953. godine, str. 59-60.

66 ABiH, Predsjedništvo Vlade Bosne i Hercegovine, kut. 44, dok. br. 101/45., Okružni narodni odbor Banja Luka Predsjedništvu Vlade Bosne i Hercegovine, Izvještaj o radu i stanju narodnih odbora u okrugu, 27. 11. 1945.; H. Kamberović, Prema modernom druśtvu. Bosna i Hercegovina od 1945. do 1953. godine, str. 60.

67 Usp. Verbrechen an den Deutschen in Jugoslawien 1944-1948, str. 219-228; Genocide of the Ethnic Germans in Yugoslavia 1944-1948, str. 121-127; Genocid nad nemačkom manjinom u Jugoslaviji 1944-1948, str. 152-162; Vladimir Geiger, "Epidemija tifusa u logorima za folksdojčere u Slavoniji 1945./1946. i posljedice", u: Časopis za suvremenu povijest, 2/2007., Zagreb, str. 367-383. I tamo navedeni izvori i literatura.

68 SKupina AUTORA, Ženski biografski leksikon - Sjećanje žena na život u socijalizmu, str. 191-194. ["Evelina Pantner"]; T. VukšIć, "Međucrkveno i međunacionalno pitanje u djelu i misli biskupa Alfreda Pichlera (I.)", str. 138-139. ["Župnik Pichler i logorski čuvar Milan"]; Z. Sulejmanpašić, Više nas nisu hapsili 1931.-1950., str. 230-238. [Pisma majke iz logora Topola i dopisnice sestre Azre koja ju je posjetila u zatočeništvu]. 
ma Nemaca - civila". ${ }^{69}$ Ministarstvo unutarnjih poslova Vlade NR Bosne i Hercegovine proslijedilo je 18. lipnja 1946. načelniku Odjeljenja unutarnjih poslova pri Okružnom narodnom odboru Banja Luka uputstva i kućni red za logor Nijemaca civila, koje trebaju dostaviti Upravi logora Nova Topola kod Bosanske Gradiške te obrasce za evidentiranje korištenja logoraške radne snage. ${ }^{70}$

Prije toga postupanje $s$ interniranim folksdojčerima bilo je, očito, samovoljno i neujednačeno. Ujedno, kako je u provođenju odluke o internaciji folksdojčera sve vrijeme dolazilo do mnogobrojnih i različitih nepravilnosti, Ministarstvo unutarnjih poslova DF Jugoslavije, Beograd, donijelo je konačno 3. ožujka 1946. upute i tumačenje tko podliježe odluci o upućiva- nju u logore te su zatim tijekom ožujka 1946. odjeli za izvršenje kazni MUP-a narodnih republika dostavili okružnim odjelima unutarnjih poslova "načelno uputstvo o upućivanju u logore osoba njemačke narodnosti". ${ }^{71}$ Prema uputama Ministarstvo unutarnjih poslova DF Jugoslavije oslobođena su iz logora "lica njemačke narodnosti", "... koja se za vrijeme okupacije nisu isticala kao suradnici okupatora i nisu bili članovi 'kulturbunda' te njemačkih organizacija, (...) koja se nalaze u braku s licem od priznatih narodnosti /mješoviti brakovil, (...) koja su bila u J.A. ili imaju nekoga od bliže rodbine u J.A., (...) koja su aktivno sarađivala s N.O.P.-om, (...) koja su državljani neutralnih ili savezničkih država, (...) koja su za vrijeme okupacije odbila da se deklarisaju kao Njemci, (...) koja su

69 Usp. Milko Mikola (zbral in uredil), Dokumenti in pričevanja o povojnih koncentracijskih taboriščih v Sloveniji. Koncentracijska taborišča Strnišče, Hrastovec, Brestrnica in Filovci, Ministrstvo za pravosodje Republike Slovenije, Ljubljana, 2007., str. 36-39; MiLко Mıкоla (zbral), Dokumenti in pričevanja o povojnih izgonih prebivalstva $v$ Sloveniji, Študijski center za narodno spravo, Ljubljana, 2009., str. 36-39.

70 Privatno vlasništvo, Ministarstvo unutrašnjih poslova Vlade Narodne Republike B. i H., Pov. broj 2425/46 Sarajevo, 18 juna 1946 god., Predmet: Uputstva i kućni red za logor Njemaca-civila, Odjeljenju za izvršenje kazni, Načelniku unutrašnjih poslova pri ONO-u Banja Luka.

71 Privatno vlasništvo, Narodna Republika Hrvatska Ministarstvo unutrašnjih poslova Odjel za izvršenje kazni, Pov. br. 421-1946. U Zagrebu, dne 12. ožujka 1946. Predmet: načelno uputstvo vrhu logorisanja osoba njemačke narodnosti, Odjelu unutrašnjih poslova okruga...; DržAVni arhiv u Vukovaru Arhivski sabirni CENTAR Vinkovci (dalje: DAVU ASC VK), Gradski NO Vinkovci, Povjerljivi spisi, 62/46. Odjel Unutrašnjih poslova Okruga Brod Otsjek Narodne Sigurnosti Broj: Pov. 239/III-1/46. Brod: 11 maja 1946. god. Predmet: Logorisanje lica njemačke narodnosti - puštanje iz logora. - Odjelu Unutrašnjih poslova grada Vinkovci; V. GeIger, "Folksdojčeri - Fatum kolektivne krivnje", str. 295-296, 320-322; Partizanska i komunistička represija i zločini u Hrvatskoj 1944.-1946. Dokumenti, str. 317-319, 321-324; Partizanska i komunistička represija $i$ zločini u Hrvatskoj 1944.-1946. Dokumenti. Slavonija, Srijem i Baranja, str. 623-625; Marko Landeka (prir.), Dokumenti kotarske i gradske vlasti Vinkovaca od 1945. do 1947. godine, Državni arhiv u Osijeku, Osijek, 2007., str. 182-185; V. GeIGer, Logor Krndija 1945.-1946., str. 222-224; Partisan and Communist Repression and Crimes in Croatia 1944-1946. Documents. Slavonia, Syrmia and Baranya, str. 380-384; V. Geiger, Josip Broz Tito i ratni zločini. Bleiburg i folksdojčeri, str. 47-48; V. GeIger, "Represija nad pripadniki nemške manjšine na Hrvaškem, v Bosni in Hercegovini ter Vojvodini, 1944-1948", str. 134. 
se još prije rata asimilirali kao Hrvati, Srbi i sl. (...)." Naglašeno je da, "Sva otpuštena lica su od dana puštanja iz logora slobodni i ravnopravni građani naše zemlje sa svim pravima i dužnostima koje uživaju građani F.N.R. Jugoslavije..." Ipak, "Imovina otpuštenih lica ostaje državna svojina pošto je Odluka AVNOJ-a od 21. XI. 1944. god. o konfiskaciji imovine na snazi i ostaje na snazi. (...) Ta imovina ne može biti vraćena, niti će biti vraćena, te stoga uputite sve mjesne vlasti na postupak u tom pogledu..." Prema uputama Ministarstvo unutarnjih poslova DF Jugoslavije: "Sva lica njemačke narodnosti koja su ostala u logoru ne spadaju u naprijed navedene kategorije i nemaju uvjeta da budu otpušteni iz logora. To su lica njemačke narodnosti i njemačkog porijekla koja treba da budu repatrirana u Njemačku..."72

Logori za folksdojčere u Jugoslaviji ukinuti su do ožujka 1948. Najprije su pušteni radno sposobni, ali su bili prisilno obvezani na trogodišnji rad, uglavnom fizički, u rudnicima, tvornicama ili poljoprivrednim dobrima, te su i dalje živjeli u izrazito teškim uvjetima. Nije im bilo dopušteno da se udaljavaju iz mjesta boravka i rada bez dozvole. Neki su i dalje radili pod oružanom pratnjom i stražom, pa i bez ikakve novčane nadoknade. Položaj folksdojčera nije bio ni nakon ukidanja logora mnogo bolji. ${ }^{73}$

Kako na Potsdamskoj konferenciji savezničkih velesila pobjednica u ratu pitanje jugoslavenskih Nijemaca nije spominjano, FNR Jugoslavija je u siječnju 1946. zahtijevala od savezničkoga Kontrolnog vijeća za Njemačku, koje je prije prihvatilo nacrt o naseljavanju folksdojčera u Njemačku, da dopusti preseljavanje u Njemačku preostalih 110.000 Nijemaca iz Jugoslavije. U kolovozu 1947. i Vlada Saveza Sovjetskih Socijalističkih Republika odbacila je prijedlog Jugoslavije iz srpnja 1946. da se preostalih 110.000 jugoslavenskih folksdojčera iseli u sovjetsku okupacijsku zonu Njemačke. ${ }^{74}$

72 DAVU ACS VK, Gradski narodni odbor Vinkovci, Povjerljivi spisi, 62/46., Odjel Unutrašnjih poslova Okruga Brod Otsjek Narodne Sigurnosti, Broj: Pov. 239/III-1/46., Brod: 11 maja 1946. god., Predmet: Logorisanje lica njemačke narodnosti - puštanje iz logora. Odjelu Unutrašnjih poslova grada Vinkovci; Partizanska $i$ komunistička represija i zločini u Hrvatskoj 1944.-1946. Dokumenti, str. 321-324; V. GeIger, Logor Krndija 1945.-1946., str. 25-26; V. Geiger, Josip Broz Tito i ratni zločini. Bleiburg i folksdojčeri, str. 46.

73 Usp. Z. Janjetović, Between Hitler and Tito, Beograd, 2000., str. 289-290, Beograd, 2005., str. 281-282; ZoRAN JANJETOviĆ, "Proterivanje nemačkog i mađarskog življa iz Vojvodine na kraju Drugog svetskog rata", u: Hereticus, Vol. 5, br. 1, Beograd, 2007., str. 116; Herbert Prokle, Der Weg der Deutschen Minderheit Jugoslawiens nach der Auflösung der Lager 1948., Verlag der Donauschwäbischen Kulturstiftung, München, 2008.; V. Geiger, "Represija nad pripadniki nemške manjšine na Hrvaškem, v Bosni in Hercegovini ter Vojvodini, 1944-1948", str. 133; V. Geiger, Josip Broz Tito i ratni zločini. Bleiburg i folksdojčeri, str. 41. I tamo navedeni izvori i literatura.

74 Dokumentation der Vertreibung der Deutschen aus Ost-Mitteleuropa, Band V, Das Schicksal der Deutschen in Jugoslawien, str. 99E; D. NećAK, "O problemu 'razseljenih oseb' (D. Ps.) in jugoslovanskih 'Volksdeutscherjev' v Austriji te o britanski ideji njihove zamenjave s koroškimi Slovenci (1945 - 1947)", str. 566; V. Geiger, "Folksdojčeri - Fatum kolektivne krivnje", str. 296; Vladimir Geiger, "Volksdeutsche - Fatum der kollektiven Schuld", u: Review of Croatian History, Vol. I., No. 1, Zagreb, 2005., str. 223; Zoran Janjetović, Between Hitler and Tito, Beograd, 2000., str. 300, 307, Beograd, 2005., 
Jugoslavenske vlasti su, nakon svega, obustavile odnosno odgodile iseljavanje/protjerivanje preostalih folksdojčera iz Jugoslavije, ali isto tako nisu dopuštale povratak izbjeglih ili prognanih Nijemaca u Jugoslaviju. Konačno, "Zakonom o izmjenama i dopunama Zakona o državljanstvu FNRJ"75 od 1. prosinca 1948., pripadnicima njemačke manjine koji se ne nalaze u Jugoslaviji, koji su do tada izbjegli ili protjerani, oduzeto je državljanstvo FNR Jugoslavije, a time i mogućnost povratka u domovinu. ${ }^{76}$

Najsustavniji statistički/demografski izračuni ljudskih gubitaka Jugoslavije u Drugom svjetskom ratu B. Kočovića i V. Žerjavića iznose različite, pa i međusobno oprečne pokazatelje o demografskim i stvarnim gubitcima Nijemaca Bosne i Hercegovine. Prema Kočoviću ljudski gubitci Nijemaca Bosne i Hercegovine u Drugom svjetskom ratu iznose: demografski 19.000, a stvarni 1000 osoba. Prema Kočovićevim izračunima/procjenama zbog ratnih okolnosti nerođeno je 1000, asimilirano 2000, migriralo u Vojvodinu 1000, emigriralo na zapad 13.000, emigriralo na istok 1000, odnosno ukupno nepoginulo 18.000 Nijemaca Bosne i Hercegovine. Kočović napominje, ukoliko je bilo manje asimiliranih (u slučaju bosanskohercegovačkih Nijemaca "pohrvaćenih"), da je utoliko manje stvarnih ljudskih gubitaka kod bosanskohercegovačkih Hrvata, i obratno. Kod asimiliranih, u ovom slučaju "pohrvaćenih" bosanskohercegovačkih Nijemaca ishod je, pak, obratan, ali je možda bilo više emigracije. ${ }^{77}$ Prema Žerjaviću ljudski gubitci Nijemaca Bosne i Hercegovine u Drugom svjetskom ratu iznose: demografski 16.000 (uključujući asimilaciju), a stvarni 1000 osoba. Prema Žerjavićevim izračunima/procjenama 1941. trebalo je u Bosni i Hercegovini biti 16.000, a 1948. 17.000 Nijemaca. Popis stanovništva FNR Jugoslavije 1948. zabilježio je oko 1000 Nijemaca u Bosni i Hercegovini, što Žerjavić pojašnjava demografskim gubitcima 14.000 odnosno 16.000 (plus asimilacija 2000), te zbog ratnih okolnosti nerođenih 1000 i emigracijom oko 12.000 osoba. $^{78}$ Prema, pak, izračunu/

str. 291-292, 298-299; Z. Janjetović, "Proterivanje nemačkog i mađarskog življa iz Vojvodine na kraju Drugog svetskog rata", str. 114; M. Portmann, Die kommunistische Revolution in der Vojvodina 1944-1952. Politik, Gesellschaft, Wirtschaft, Kultur, str. 264266; V. GeIger, "Represija nad pripadniki nemške manjšine na Hrvaškem, v Bosni in Hercegovini ter Vojvodini, 1944-1948", str. 134.

75 Usp. Službeni list Federativne Narodne Republike Jugoslavije, god. IV., br. 105, Beograd, 4. 12. 1948., str. 1.

76 V. Geiger, "Folksdojčeri - Fatum kolektivne krivnje", str. 297; Vladimir Geiger, "Pravo na zavičaj", Dijalog povjesničara-istoričara, 6, Zagreb, 2002., str. 355-356; V. GeIGer, "Volksdeutsche - Fatum der kollektiven Schuld", str. 224; V. Geiger, "Josip Broz Tito i sudbina jugoslavenskih Nijemaca", str. 815; V. GeIger, Josip Broz Tito i ratni zločini. Bleiburg i folksdojčeri, str. 49; V. GEIGER, "Represija nad pripadniki nemške manjšine na Hrvaškem, v Bosni in Hercegovini ter Vojvodini, 1944-1948", str. 134.

77 Usp. B. Kočović, Žrtve Drugog svetskog rata u Jugoslaviji, London, 1985., str. 70-71, 171, 174, 181-182, 189, Sarajevo, 1990., str. 56-57, 161, 164, 171-172, 179 ili B. Kočović, Sahrana jednog mita. Žrtve Drugog svetskog rata u Jugoslaviji, str. 56-57, 161, 164, 171-172, 179.

78 Usp. V. ŽERJavić, Gubici stanovništva Jugoslavije u drugom svjetskom ratu, str. 36, 54, 61, 73; V. ŽErJavić, Opsesije i megalomanije oko Jasenovca i Bleiburga. Gubici stanovništva 
procjeni Ž. Đorđevića demografski gubitci Nijemaca Bosne i Hercegovine u Drugom svjetskom ratu iznose 19.000. Prema Đorđevićevim izračunima/procjenama 1941. trebalo je u Bosni i Hercegovini biti 18.000, a 1948. 20.000 Nijemaca. ${ }^{79}$ No, upitni su i Kočovićevi pa i Đorđevićevi i napose Žerjavićevi, izračuni/procjene ljudskih gubitaka Nijemaca Bosne i Hercegovine u Drugom svjetskom ratu. Osim službenih podataka popisa stanovništva iz 1931. i 1948., koje i Kočović i Žerjavić uzimaju kao polazište u svojim izračunima/ procjenama, ostale brojke koje iznose su pretpostavke i nagađanja. Ponajprije, riječ je o u poraću asimiliranim, "pohrvaćenim", Nijemcima u Bosni i Hercegovini, oko 2000 i kod Kočovića i kod Zerjavića. Proizvoljan je i očito netočan Żerjavićev izračun/procjena o broju od oko 12.000 tijekom Drugoga svjetskog rata emigriralih bosanskohercegovačkih Nijemaca.

Povijest i sudbina Nijemaca Bosne i Hercegovine obrađena je ponajprije $u$ radovima njemačkih i austrijskih autora, podrijetlom iz Bosne i Hercegovine, ali i u radovima njemačkih i austrijskih povjesničara. ${ }^{80}$ Historiografija, i nje- mačka i austrijska i jugoslavenska, sustavno su obradile i iseljavanje bosanskohercegovačkih Nijemaca tijekom Drugoga svjetskog rata, ponajprije 1942., redovito navodeći da je prema izvorima taj broj oko 18.000 , uključivo $s$ tada iseljenim hrvatskim Nijemcima u Njemački Reich. Naime, prema svim pokazateljima, potkraj 1942. iseljeno je u Njemački Reich oko 15.000 ili nešto više bosanskohercegovačkih Nijemaca, a procjene i navodi o broju Nijemaca iseljenih, izbjeglih i protjeranih iz Bosne i Hercegovine tijekom 1943., 1944. i 1945. do potkraj Drugoga svjetskog rata u rasponu je od 1500 do 3000 osoba. Prema njemačkim/ podunavskošvapskim navodima, utemeljenim na procjenama, izračunima i popisima, tijekom Drugoga svjetskog rata i u poraću, život je izgubio 1301 Nijemac Bosne i Hercegovine, od čega 110 osoba kao civili tijekom rata, 130 osoba kao civili u logorima u poraću, od 1945. do 1948., a 211 osoba život je izgubilo od komunističke vlasti, i najviše njih 850 život je izgubilo kao vojnici, pripadnici oružanih snaga NDH i Njemačkoga Reicha, tijekom Drugoga svjetskog rata. ${ }^{81}$

Jugoslavije u drugom svjetskom ratu, str. 133, 150, 157, 168; V. ŽErJavić, Population losses in Yugoslavia 1941-1945, str. 135, 146, 150, 156; V. ŽErJavić, Pertes de la population en Yougoslavie 1941-1945, str. 144, 154, 158, 164.

79 Usp. Ž. ĐorĐević, Gubici stanovništva Jugoslavije u Drugom svetskom ratu, str. 158-159, 161.

80 Usp. Vladimir Geiger, "Bosna u folksdojčerskoj historiografiji i publicistici", u: Bosna franciscana, br. 15, Sarajevo, 2001., str. 220-227; L. PerenčEvić, "'Pravo na zavičaj' Identitet bosanskih Nijemaca u poslijeratnoj Njemačkoj", str. 164-177; L. PerenčEvić, "'Fern vom Land der Ahnen' - Zur Identitätskonstruktion in bosniendeutschen Heimatbüchern", str. 59-70.

81 Usp. Leidensweg der Deutschen im kommunistischen Jugoslawien, Band IV, Menschenverluste - Namen und Zahlen zu Verbrechen an den Deutschen durch das Tito-Regime in der Zeit von 1944-1948, str. 1015; K. WeBer, Bevölkerung und Verluste. Die demographische Erfassung der Jugoslawiendeutschen, str. 73; Verbrechen an den Deutschen in Jugoslawien 1944-1948. Die Stationen eines Völkermords, str. 314; Dieter Blumenwitz, Rechtsgutachen über die Verbrechen an den Deutschen in Jugoslawien 1944-1948, Verlag 
Prvi je poslijeratni popis 1948. zabilježio u Jugoslaviji 55.337 (u Bosni i Hercegovini 1174) pripadnika njemačke manjine ${ }^{82}$ (Austrijanci su na popisu 1948. uključeni, zbog neznatnog broja iskazanih pripadnika, u skupinu "Ostali"), što pak najslikovitije svjedoči o njihovoj sudbini.

Položaj njemačke manjine u Jugoslaviji donekle će se poboljšati nakon što je 1951. FNR Jugoslavija donijela ukaze o ukidanju ratnoga stanja $s$ Austrijom i Njemačkom. ${ }^{83}$ Iseljavanje folksdojčera iz Jugoslavije, bilo je tada još uvijek moguće samo preko liste Crvenog križa u sklopu programa spajanja obitelji. Od 1952., nakon dogovora jugoslavenske i njemačke vlade da se preostali folksdojčeri mogu iseliti u Njemačku, odobravalo se i pojedinačno iseljavanje. Nakon što je 1953., odnosno 1954. potpisan i sporazum između austrijske i jugoslavenske vlade o otpustu folksdojčera iz jugoslavenskog državljanstva i mogućnosti stjecanja austrijskog, ${ }^{84}$ od 1955. iseljavanje njemačke i austrijske manjine iz Jugoslavije znatno je pojednostavljeno. ${ }^{85}$ Stoga, popisi stanovništva i Jugoslavije, i Bosne i Hercegovine, i 1953. i nadalje bilježe nastavak znatnog smanjenja broja $\mathrm{Ni}$ jemaca (i Austrijanaca). ${ }^{86}$

Jugoslavenska, i bosanskohercegovačka, socijalistička historiografija jednostrano je prikazivala i u mnogočemu neutemeljeno sotonizirala Nijemce i Austrijance Bosne i Hercegovine, napose u vrijeme Drugoga svjetskog rata. Zastupnici takvih stajališta o jugoslavenskim i bosanskohercegovačkim Nijemcima nisu posustali ni nakon raspada SFR Jugoslavije. Mnogi rado prešućuju i zaboravljaju gospodarski i kulturni rad i zasluge Austro-Ugarske Monarhije i doseljenih Nijemaca i Austrijanaca za napredak Bosne i Hercegovine. Mišljenja smo da je, ipak, neophodan drukčiji pristup povijesti Nijemaca i Austrijanaca Bosne i Hercegovine.

der Donauschwäbischen Kulturstiftung, München, 2002., str. 61; Genocide of the Ethnic Germans in Yugoslavia 1944-1948, str. 166.

82 Usp. Konačni rezultati popisa stanovništva od 15. marta 1948. godine, knj. IX, Stanovništvo po narodnosti, Beograd, 1954.; Stanovništvo Bosne i Hercegovine. Narodnosni sastav po naseljima, Državni zavod za statistiku RH, Zagreb, 1995., str. 9.

83 Službeni list Federativne Narodne Republike Jugoslavije, god. VII, br. 4, Beograd, 17. 1. 1951., str. 68-69; Službeni list Federativne Narodne Republike Jugoslavije, god. VII, br. 35, Beograd, 1. 8. 1951., str. 1.

84 Službeni list Federativne Narodne Republike Jugoslavije. Medunarodni ugovori i drugi sporazumi, god. III., br. 5, Beograd, 15. 7. 1955., str. 56.

85 DUŠAn NeĆAK, "Nekaj osnovnih podatkov o usodi nemške narodnosne skupnosti v Sloveniji po letu 1945", u: Zgodovinski časopis, št. 3, Ljubljana, 1993., str. 444; V. Geiger, "Represija nad pripadniki nemške manjšine na Hrvaškem, v Bosni in Hercegovini ter Vojvodini, 1944-1948", str. 135.

86 Usp. Jugoslavija 1918-1988. Statistički godišnjak SFRJ, Savezni zavod za statistiku, Beograd, 1989., str. 45; Stanovništvo Bosne i Hercegovine. Narodnosni sastav po naseljima, str. 9. 


\section{A brief historical overview of the position of Germans and Austrians in Bosnia and Herzegovina, with particular reference to the period during and after World War II}

\section{Summary}

Based on numerous and valuable historiographic, fictional and demographic articles as well as published and archived sources, the paper reflects on the history and the destiny of Germans and Austrians in Bosnia and Herzegovina since the time of the Austro-Hungarian occupation and their settling here in the late 19th century, through the period of the Kingdom of SHS / Yugoslavia, when although a small ethnic group of about twenty thousand they became an important economic and cultural factor, to World War II and immediate post-war time, when they suffered significant demographic and real losses, and 'disappeared' from the Bosnian-Herzegovinian ground.

Yugoslav and Bosnian-Herzegovinian socialist historiography unilaterally depicted and in many ways unfoundedly satanized Germans and Austrians in Bosnia and Herzegovina, especially during World War II. Those with such standpoints on Yugoslav and Bosnian-Herzegovinian Germans did not stop even after the dissolution of Yugoslavia. Many people remained silent and forgot about the economic and cultural work and merits of the Austro-Hungarian Empire and immigrant Germans and Austrians in the progress of Bosnia and Herzegovina. This paper, however, offers a different approach to the history of Germans and Austrians in Bosnia and Herzegovina.

Keywords: Bosnia and Herzegovina, Germans, Austrians. 